\title{
Ammonia and urea transport across the rumen epithelium: a review
}

\author{
Khalid Abdoun ${ }^{1 * \dagger}$, Friederike Stumpff ${ }^{2 \dagger}$ and Holger Martens ${ }^{2}$ \\ ${ }^{1}$ Faculty of Veterinary Medicine, University of Khartoum, P.O. Box 32, 13314 Khartoum North, \\ Sudan and ${ }^{2}$ Department of Veterinary Physiology, Freie Universität Berlin, Oertzenweg 19b, 14163 \\ Berlin, Germany
}

Received 7 June 2006; Accepted 21 August 2006

\begin{abstract}
The transport of nitrogen across the rumen epithelium is characterized by absorption of ammonia from the rumen and by an influx of urea into the rumen. The transport rates of both compounds are large and exhibit wide variation. The transport of ammonia occurs in two forms: in the lipophilic form as $\mathrm{NH}_{3}$, the magnitude of which is linearly related to the $\mathrm{pH}$ in the ruminal fluid at $\mathrm{pH}$ values above 7 , while at a physiological $\mathrm{pH}$ of 6.5 or lower, ammonia is predominantly absorbed as $\mathrm{NH}_{4}{ }^{+}$via putative potassium channels in the apical membrane. The uptake of $\mathrm{NH}_{4}{ }^{+}$depends on the potential difference of the apical membrane, $\mathrm{Pd}_{\mathrm{a}}$, and shows competition with $\mathrm{K}$ uptake. The pathway for basolateral exit of $\mathrm{NH}_{4}{ }^{+}$is unknown. Hence, the relative transport rates of $\mathrm{NH}_{3}$ or $\mathrm{NH}_{4}{ }^{+}$are determined by the ruminal $\mathrm{pH}$ according to the Henderson-Hasselbalch equation. Transport of ammonia interacts with the transport of Na and $\mathrm{Mg}$ mainly via changes of the intracellular $\mathrm{pH}$. Urea recycling into the rumen has been known for many years and the transport across the rumen epithelium is mediated via urea transporters in the luminal and basolateral membrane of the epithelium. Transport of urea occurs by simple diffusion, but is highly variable. A significant increase of urea influx is caused by the fermentation products $\mathrm{CO}_{2}$ and short-chain fatty acids. Conversely, there is some evidence of inhibition of urea influx by ruminal ammonia. The underlying mechanisms of this modulation of urea transport are unknown, but of considerable nutritional importance, and future research should be directed to this aspect of ruminal transport.
\end{abstract}

Keywords: rumen, ammonia, urea, transport, ruminants

\section{Introduction}

The maintenance of an optimum nitrogen balance in ruminants for growth, pregnancy and lactation is of key economic importance, requiring a wide range of adaptive responses to supply the necessary nitrogenous metabolites for different physiological states. The splanchnic bed, comprising the gastrointestinal tract and liver, plays a pivotal role in moderating the pattern of nitrogenous nutrients available for peripheral tissues. The

*Corresponding author. E-mail: abdounn@yahoo.com

${ }^{\dagger} \mathrm{K}$. Abdoun and F. Stumpff contributed equally to this review. gastrointestinal tissues form an interface between the diet and the animal and have a direct influence on the flux of nitrogenous nutrients from the gut lumen into the bloodstream. The liver then forms the central metabolic junction, further moderating and distributing nitrogenous nutrients to peripheral tissues for maintenance or productive functions such as muscle deposition or milk synthesis.

The transport of nitrogen across the rumen epithelium is characterized by absorption of ammonia ${ }^{\ddagger}$ (McDonald,

${ }^{\ddagger}$ The term ammonia is used without discrimination between $\mathrm{NH}_{3}$ and $\mathrm{NH}_{4}{ }^{+}$. Chemical symbols are used, when a specification is required. 
1948) from the rumen and by an influx of urea into the rumen (see review of Harmeyer and Martens, 1980; Marini et al., 2006).

Total ammonia absorption from the gastrointestinal tract represents approximately half of the absorbed $\mathrm{N}$ and ammonia absorption from the forestomachs amounts to roughly $50 \%$ of total flow of ammonia to the liver (Reynolds and Huntington, 1988; Huntington, 1989; Huntington et al., 1996; Theurer et al., 2002), although for unknown reasons, considerable variation is known to occur. Absorbed ammonia is detoxified into urea in the liver.

Total urea-N synthesis exceeds flow of ammonia-N to the liver and is explained by transfer of nitrogen from amino acids for urea production (Reynolds, 1995). The daily urea-N turnover accounts for more than $50 \%$ of the total $\mathrm{N}$ intake from the gastrointestinal tract (Harmeyer and Martens, 1980), most of which is recycled to ruminal tissue. In a recent study of Theurer et al. (2002), $77 \%$ of urea production was transferred through the rumen epithelium. This magnitude of urea recycling has also been reported in other studies (Reynolds and Huntington, 1988; Huntington et al., 1996).

Urea produced in the liver passes into the digestive tract and is broken down by resident bacteria into ammonia and $\mathrm{CO}_{2}$ (Lapierre and Lobley, 2001). The bacteria use ammonia to synthesize amino acids and peptides required for synthesis of microbial protein, which is digested and absorbed in the small intestine, thus completing the 'salvaging' of urea nitrogen (Fuller and Reeds, 1998). The salvage mechanism via urea recycling is central to the ability of the ruminant to subsist on a low protein diet since $\mathrm{N}$ is re-directed to productive uses via microbial protein synthesis, instead of being excreted in urine. The recycling of urea and the reuse of nitrogen for microbial protein synthesis, which covers up to $80 \%$ of protein requirement of the ruminant, is unique and one important reason for the widespread occurrence of ruminants in many habitats.

Many studies have been performed to quantify the large amounts of nitrogen passing the rumen epithelium per day as ammonia (absorption) or urea (influx) under a variety of feeding conditions (see reviews of Reynolds, 1995, 2006; Lappiere et al., 2005). In contrast, surprisingly little attention has been paid to the mechanisms of ammonia and urea transport across the rumen epithelium. It is therefore the intention of this paper to review primarily data of ammonia and urea transport across the rumen epithelium. The factors that affect ammonia and urea transport will be discussed and the effects of ammonia on transport of $\mathrm{Mg}$ and $\mathrm{Na}$ will also be incorporated. Within this framework, briefly, metabolism of ammonia in the rumen, its flow to and detoxification in the liver are included and some aspects of urea recycling will be discussed.

\section{Ammonia production in the rumen}

Ammonia is generated in the rumen (and in the gut) of all animal species as a result of two main processes:

(i) microbial degradation of nitrogenous compounds such as protein, peptides, amino acids and nucleic acids; and

(ii) microbial hydrolysis of urea passing across epithelia of the gastrointestinal tract from the blood and interstitial fluids and urea flowing into the rumen via saliva.

Protein degradability in the rumen is dependent on many factors including solubility, susceptibility to microbial proteases and residence time in the rumen (Taminga, 1983). These factors combine to produce a pattern of release of peptides, amino acids and $\mathrm{NH}_{3}$, all of which provide a source of $\mathrm{N}$ for microbial protein synthesis.

The relationship between $\mathrm{N}$ intake and ammonia irreversible loss rates within the rumen have been studied over a wide range of $\mathrm{N}$ source and level in the diet of sheep (Mathison and Milligan, 1971; Nolan, 1975; Nolan et al., 1976; Siddons et al., 1985; Kennedy et al., 1986). They indicated that $50 \%$ of dietary $\mathrm{N}$ entering the rumen had already previously passed directly through the rumen $\mathrm{NH}_{3}$ pool and that $3.8 \mathrm{~g} \mathrm{day}^{-1}$ ammonia-N was produced from endogenous sources (recycling) within the rumen of sheep. Most of these studies were carried out on sheep as a model for ruminants. Extrapolating these data to lactating cows, large amounts of ammonia are released and account for $38 \mathrm{gday}^{-1}$ ammonia-N at maintenance and to some $300 \mathrm{~g} \mathrm{day}^{-1}$ at a milk production of $401 \mathrm{day}^{-1}$ assuming that $50 \%$ of dietary $\mathrm{N}$ passes through the ruminal ammonia pool ( $\mathrm{N}$ intake - crude protein - according to the recommendation of the Gesellschaft für Ernährungsphysiologie, Germany).

Numerous experiments have demonstrated the impact of either concentrate- or forage-based diets on rumen ammonia levels within various time periods after feeding (Wernli and Wilkins, 1980). Effects are particularly pronounced in the case of silage feeding, where the soluble nitrogenous components are rapidly degraded in the rumen to result in peaks of ammonia concentration of $18-20 \mathrm{mM}$ within $1 \mathrm{~h}$ after feeding from basal levels of $2-4 \mathrm{mM}$. This level can be attenuated by chemical treatment of the forage material before ensilage by using acid formaldehyde to reduce $\mathrm{N}$ solubility (Thompson et al., 1981) or by provision of a readily fermentable carbohydrate to provide energy for $\mathrm{N}$ capture by the rumen microflora (Rooke et al., 1987). Rumen infusion studies in which either pulsed or continuous infusions of $\mathrm{N}$ and energy-yielding substrates have been used (Henning et al., 1993) demonstrate that providing a constant supply of energy may be a critical factor in improving nutrient utilization. In the absence of such 
provision, rapid fluctuations in ammonia concentration occur. Periods during which rumen ammonia levels rise above or fall below the range thought to be optimal for microbial growth and microbial protein production of $3.5 \mathrm{mM}$ (Satter and Slyter, 1974) to $6 \mathrm{mM}$ (KangMeznarich and Broderick, 1981) result in inefficient use of $\mathrm{N}$ for microbial protein synthesis and loss of ammonia from the rumen by absorption across the gut wall, thereby reducing both energy and protein supply to the host animal.

Synchronization of $\mathrm{N}$ and energy release within the rumen in order to maximise nutrient capture by microbial populations has been an objective of ruminant feeding systems (see review of Blank et al., 1998). Experiments in sheep (Sinclair et al., 1993) in which diets were formulated on the basis of either asynchronous or synchronous release of nutrients have shown that manipulation of the pattern of substrate availability in this way can provide a practical method of improving the efficiency of $\mathrm{N}$ capture and reducing the magnitude of rumen ammonia cycling.

Ammonia is an essential source of nitrogen for microbial growth. Although early work (Bryant and Robinson, 1962) indicated that about 90\% of bacterial species within the rumen could utilise ammonia as the main source of $\mathrm{N}$ for growth, further studies have demonstrated a potential for free amino acids and peptides to become incorporated into microbial protein without passing through the rumen ammonia pool (Cotta and Hespell, 1986; MacKie and White, 1990). More recent studies have shown that for a range of feed protein sources, a maximum of $40-70 \%$ of microbial $\mathrm{N}$ was derived from the rumen $\mathrm{NH}_{3}$ pool (Hristov and Broderick, 1994).

\section{Ammonia absorption from the rumen}

Ammonia disappears from the rumen by incorporation into microbial proteins, absorption across the rumen epithelium (35-65\% of the ammonia loss from the rumen), or by the outflow of ruminal fluid into the omasum (10\% of the loss) (Nolan and Strachin, 1979; Siddons et al., 1985; Obara et al., 1991). Loss of ammonia by absorption through the rumen wall can be quantitatively very high and account for some 50\% ammonia flow to the liver (see above). This absorption was first clearly demonstrated by McDonald in 1948. Since then, numerous studies have been carried out to try to determine the form $\left(\mathrm{NH}_{3}\right.$ or $\left.\mathrm{NH}_{4}^{+}\right)$and mechanisms governing this absorption.

The luminal uptake of ammonia across the apical membrane into the cytosol of rumen epithelial cells $\left(J_{\mathrm{Lu} \rightarrow \mathrm{Cyt}}\right)$ is the sum of parallel movement of the nonionized and ionized form:

$$
J_{\mathrm{Lu} \rightarrow \mathrm{Cyt}}={ }_{\mathrm{Lu} \rightarrow \mathrm{Cyt}} \mathrm{NH}_{3}{ }^{+} \mathrm{Lu} \rightarrow \mathrm{Cyt} \mathrm{NH}_{4}{ }^{+}
$$

The subscripts Lu and Cyt denote lumen and cytosol, respectively. Assuming a simple diffusive movement $(\mathrm{Lu} \rightarrow \mathrm{Cyt})$, the flux rates of $\mathrm{NH}_{3}$ and $\mathrm{NH}_{4}{ }^{+}$are determined by a product of permeability and a driving force:

$$
J_{\mathrm{Lu} \rightarrow \mathrm{Cyt}}=P_{\mathrm{NH} 3} \cdot\left[\mathrm{NH}_{3}\right]+P_{\mathrm{NH} 4}{ }^{+} \cdot\left[\mathrm{NH}_{4}{ }^{+}\right] \cdot \xi
$$

where $P_{\mathrm{NH} 3}$ and $P_{\mathrm{NH} 4}{ }^{+}$are the permeabilities of the apical membrane to $\mathrm{NH}_{3}$ and $\mathrm{NH}_{4}{ }^{+}$, respectively, and $\left[\mathrm{NH}_{4}{ }^{+}\right]$ and $\left[\mathrm{NH}_{3}\right]$ refer to the concentration of the two forms of ammonia in the lumen. The driving force is given by $\xi=z \cdot F \cdot \operatorname{Pd}_{\mathrm{a}} /\left\{R \cdot T \cdot\left[\exp ^{(z \cdot F \cdot \mathrm{Pda} / R \cdot T)}-1\right]\right\}$, in which $\mathrm{Pd}_{\mathrm{a}}$ is the potential difference across the luminal membrane of the epithelial cell and $z, F, R$ and $T$ have the usual electrochemical meanings.

The relative concentrations and subsequent flux rates of $\mathrm{NH}_{3}$ and $\mathrm{NH}_{4}{ }^{+}$can be altered by the luminal $\mathrm{pH}$ according to the Henderson-Hasselbalch equation. The wide variations in the ruminal ammonia concentrations (up to $70 \mathrm{mM}$ ) and of $\mathrm{pH}(5.4-7.4)$ cause corresponding alterations of $\mathrm{NH}_{3}$ and $\mathrm{NH}_{4}{ }^{+}$concentrations and flux rates across the rumen epithelium (Fig. 1).

\section{Flux of $\mathrm{NH}_{3}$}

Ammonia is a weak base with a pKa of 9 (Leng and Nolan, 1984). The Henderson-Hasselbalch equation shows that at $\mathrm{pH}$ values between 6 and 7 , practically all the ammonia will be in its ionized form (99.9 and 98.7\%, respectively) (Fig. 1A), that is, in the form that will diffuse poorly across the lipid layers of the cell membranes. It has been demonstrated that even at these neutral $\mathrm{pH}$ values, absorption of ammonia takes place and increases with the intraruminal ammonia concentration (Hogan, 1961; Bödeker et al., 1990; Remond et al., 1993a) and pH (Gärtner and v. Engelhardt, 1964). When the intraruminal $\mathrm{pH}$ is lowered, the permeability of the rumen wall for ammonia is depressed (Hogan, 1961; Chalmers et al., 1971; Bödeker et al., 1990), so that ammonia absorption remains stable despite the increase in intraruminal ammonia concentration (Hogan, 1961). These findings are generally taken as evidence that ammonia absorption across the epithelium of the rumen occurs by simple diffusion of the non-ionized lipid soluble form $\left(\mathrm{NH}_{3}\right)$.

\section{Flux of $\mathrm{NH}_{4}^{+}$}

The possibility of ammonium ion $\left(\mathrm{NH}_{4}{ }^{+}\right)$absorption from the digestive contents has also been considered (Hogan, 1961; Siddons et al., 1985), but as this form is weakly lipid-soluble, its movement across the membranes of the epithelial cells would require the assistance of carriers or channels. Bödeker and Kemkowski (1996) observed that the addition of $\mathrm{NH}_{4}^{+}$to the incubation 
(A) Ratio of $\mathrm{NH}_{3} / \mathrm{NH}_{4}{ }^{+}$as a function of $\mathrm{pH}$

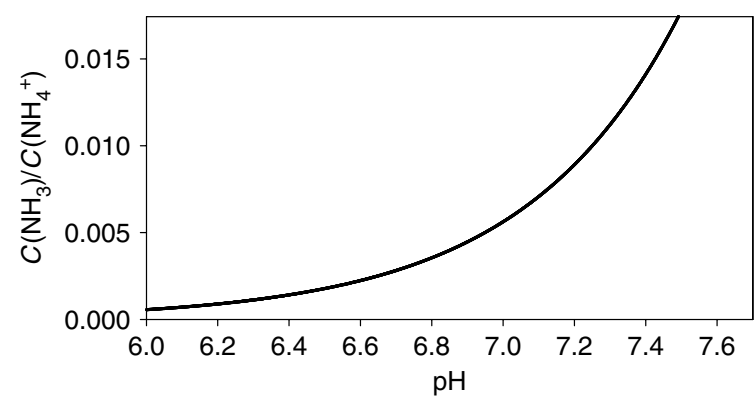

(B)

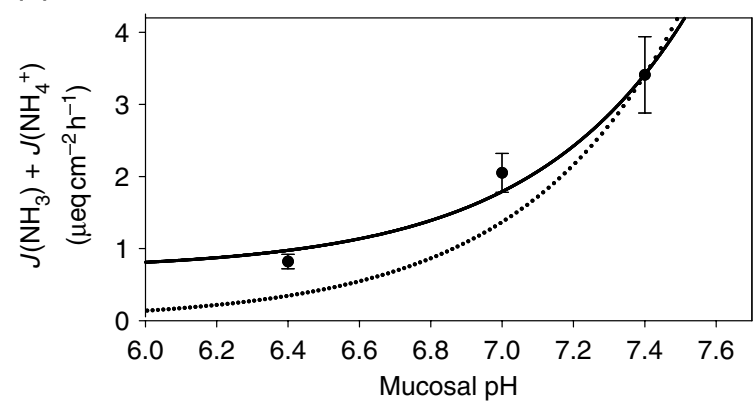

Fig. 1. (A) Correlation between $\mathrm{pH}$ and the ratio between ammonia and ammonium $\left(\left[\mathrm{NH}_{3}\right] /\left[\mathrm{NH}_{4}{ }^{+}\right]\right)$as given by the Henderson-Hasselbalch equation and (B) correlation between mucosal $\mathrm{pH}$ and total flux of ammonia across the ruminal epithelium. (A) The concentration of the nonionized form of ammonia $\left[\mathrm{NH}_{3}\right]$ increases 10 -fold when the mucosal $\mathrm{pH}$ is increased from 6.4 to 7.4 , while the concentration of $\left[\mathrm{NH}_{4}{ }^{+}\right]$remains almost constant. (B). The dots with error bars (\$) designate the measured flux of both charged and uncharged ammonia $\left(\mathrm{NH}_{3}+\mathrm{NH}_{4}{ }^{+}\right)$through the ruminal epithelium at different values of mucosal $\mathrm{pH}$. Ammonia fluxes fall off with $\mathrm{pH}$ and falling concentrations of $\mathrm{NH}_{3}$, but not as rapidly as predicted by HendersonHasselbalch theory (dotted curve: the flux of ammonia is assumed to decrease linearly with the concentration of $\mathrm{NH}_{3}$ as given by the Henderson-Hasselbalch equation from the measured value at $\mathrm{pH}$ 7.4). A better correlation of the data with theoretical predictions can be achieved if an additional flux of ammonium in its charged form $\left(\mathrm{NH}_{4}{ }^{+}\right)$ at a constant rate of $0.7 \mu \mathrm{eq} \mathrm{cm}^{-2} \mathrm{~h}^{-1}$ is assumed to contribute to total ammonium transport (Abdoun et al., 2005) (solid curve; again, the flux data at $\mathrm{pH} 7.4$ are used as a starting point). This assumption is supported by interactions of ammonium with uptake of $\mathrm{Na}$ via NHE. For details, see text.

solution on the mucosal side of sheep rumen epithelium in vitro evoked positive short-circuit currents $\left(I_{\mathrm{sc}}\right)$, which were blocked by quinidine. Moreover, they reported a reduction of the transepithelial ammonia fluxes in the presence of quinidine in the incubation solution or alternately when the transepithelial potential difference was clamped to $+25 \mathrm{mV}$. They suggested that $\mathrm{NH}_{4}{ }^{+}$takes part in ammonia transport across the rumen epithelium, most probably via a $\mathrm{K}^{+}$channel.

\section{Presence of $K^{+}$channels in rumen epithelium}

The ruminal epithelium was one of the first epithelia in which potassium secretion was observed in vivo (Sperber and Hyden, 1952; Hyden, 1961; Ferreira et al., 1966a) and in vitro (Ferreira et al., 1966b, 1972; Wolffram et al., 1989; Leonhard-Marek and Martens, 1996) via an ouabainsensitive mechanism (Harrison et al., 1975). At higher concentrations of ruminal potassium, absorption of potassium can be observed that is correlated to the ruminal potassium concentration, but remains slow and much lower than absorption rates for sodium, suggesting a passive efflux pathway (Hyden, 1961; Warner and Stacy, 1972a, b).

With rising concentrations of ruminal potassium, the potential across the ruminal epithelium rises in vivo (Sellers and Dobson, 1960; Scott, 1966; Ferreira et al., 1966a; Care et al., 1984; Martens and Blume, 1986) and in vitro (Ferreira et al., 1966b; Harrison et al., 1975; Leonhard-Marek and Martens, 1996), and may limit the driving force for passive efflux of potassium from the rumen (Dobson, 1959). The notion of an electrogenic, transcellular pathway for ruminal potassium transport is supported by the observation of apical potassium secretion at low concentrations of potassium as mentioned above, and by the depolarization of the apical membrane of the ruminal epithelium in high potassium solutions with a concomitant decrease in the fractional apical resistance (Leonhard-Marek and Martens, 1996).

Elevation of ruminal potassium induces a stimulation of sodium transport out of the rumen (Hyden, 1961; Stacy and Warner, 1966; Scott, 1967; Warner and Stacy, 1972a, b; Martens and Hammer, 1981). However, attempts to block a putative Na-K-2Cl cotransport with furosemide or bumetanide in the rumen were unsuccessful (Martens et al., 1988, 1991). Indeed, a fixed coupling of $\mathrm{Na}$ with $\mathrm{K}$ transport cannot explain selective stimulation of sodium absorption that is observed after abrupt transfer of animals to a high potassium diet (Sellers and Dobson, 1960), and which results in concentration of potassium in the rumen to levels that can reach $100 \mathrm{mM}$. This effect, which plays a major role in ruminant potassium homeostasis, may involve voltage-dependent stimulation of a Napermeable cation channel (Lang and Martens, 1999; Leonhard-Marek, 2005; for a review, see Stumpff and Martens, 2006).

The model most suitable for the integration of the various data is the assumption of apical potassium channels in the ruminal epithelium and corresponding quinidine-sensitive $\mathrm{NH}_{4}{ }^{+}$and $\mathrm{K}^{+}$conducting ionic channels have been demonstrated in isolated ruminal epithelial cells (Abdoun et al., 2005). The permeability of the pore of potassium channels to $\mathrm{NH}_{4}{ }^{+}$has been demonstrated numerous times (Yellen, 1987; Choe et al., 2000; Hille, 2001). 


\section{Ruminal transport of ammonia}

The transport of ammonia across the isolated rumen of sheep has been studied in more detail by measuring the flux of ammonia in the mucosal-serosal direction at different concentrations and $\mathrm{pH}$ values in order to specify the transported form of ammonia $\left(\mathrm{NH}_{3}\right.$ or $\left.\mathrm{NH}_{4}{ }^{+}\right)$ (Abdoun et al., 2005; Fig. 1A) One approach of the study was to measure total ammonia flux at a (total) mucosal concentration of $30 \mathrm{mM}$. The mucosal $\mathrm{pH}$ was set to different $\mathrm{pH}$ values of $6.4,6.9$ and 7.4, and the corresponding flux rates of ammonia were measured. However, at acidic levels of mucosal $\mathrm{pH}$, ammonia fluxes fell off less rapidly than the concentration of $\mathrm{NH}_{3}$ (Fig. 1B), suggesting an additional flux of $\mathrm{NH}_{4}{ }^{+}$.

To assess the size of the relative contributions, concentrations of $\mathrm{NH}_{3}$ were calculated with the Henderson-Hasselbalch equation yielding 0.07 ( $\mathrm{pH}$ 6.4), to $0.27(\mathrm{pH}$ 6.9) or $0.68(\mathrm{pH} 7.4)$, respectively, while the concentrations of $\mathrm{NH}_{4}{ }^{+}$remained almost unchanged. A linear correlation was obtained (see Abdoun et al., 2005) between the measured total ammonia flux in $\mu$ eq $\mathrm{cm}^{-2} \mathrm{~h}^{-1}$ (designated as ' $y$ ') and the concentration of mucosal $\mathrm{NH}_{3}$ (designated as ' $x$ ') that took the form:

$$
\mathrm{y}=4.1 \mathrm{~cm} \mathrm{~h}^{-1} \cdot x+0.7 \mu \text { eq } \mathrm{cm}^{-2} \mathrm{~h}^{-1} \quad(r=0.99) .
$$

The linear correlation between ammonia flux and concentration of $\mathrm{NH}_{3}$ supports the classical notion of transport via lipid diffusion with a permeability constant $P\left(\mathrm{NH}_{3}\right)=J\left(\mathrm{NH}_{3}\right) /\left[A \cdot C\left(\mathrm{NH}_{3}\right)\right]$ of $4.1 \mathrm{~cm} \mathrm{~h}^{-1}=$ $1.14 \times 10^{-3} \mathrm{cms}^{-1}$ (where $J\left(\mathrm{NH}_{3}\right)$ is the flux, $A$ the surface area of the tissue, and $C\left(\mathrm{NH}_{3}\right)$ the concentration of ammonia in the form of $\mathrm{NH}_{3}$ ). Of course, it is not possible to compare this value directly to values derived from experiments with artificial lipid bilayers, since the ruminal epithelium is a multi-layered epithelium of about $70 \mu \mathrm{m}$ thickness (Dobson, 1959) and the area is enlarged by numerous papillae. However, experiments on artificial membranes yield values that are roughly in the same order of magnitude $\left(7.8 \times 10^{-2}\right.$ to $2.4 \times 10^{-3} \mathrm{~cm} \mathrm{~s}^{-1}$ ) (Lande et al., 1995) and therefore we feel that simple lipid diffusion can safely be regarded as a suitable model for the uptake route of $\mathrm{NH}_{3}$ across the ruminal epithelium until solid evidence is obtained refuting this theory.

On the contrary, the lipid diffusion model fails to explain the transport of ammonia as the concentration of $\mathrm{NH}_{3}$ approaches zero. The $y$-intercept of $0.7 \mu \mathrm{eq} \mathrm{cm} \mathrm{ch}^{-2} \mathrm{~h}^{-1}$ in the absence of $\mathrm{NH}_{3}$ should represent the flux (density) of ammonia in its charged form $\left(J\left(\mathrm{NH}_{4}{ }^{+}\right) / A\right)$. The permeability of the ruminal epithelium for $\mathrm{NH}_{4}{ }^{+}$is thus given by the quotient of the flux density $\left(0.7 \mu \mathrm{eq} \mathrm{cm}^{-2} \mathrm{~h}^{-1}\right)$ and the concentration $\left(30 \mathrm{mmoll}^{-1}\right)$, yielding a value of $P\left(\mathrm{NH}_{4}{ }^{+}\right)=$ $6.46 \times 10^{-6} \mathrm{~cm} \mathrm{~s}^{-1}$ (and thus, many orders of magnitude above the value of $10^{-11}$ to $10^{-13} \mathrm{~cm} \mathrm{~s}^{-1}$ reported for the cation permeability of lipid membranes (Paula et al., 1996)). The conclusion that an electrogenic, facilitated transport (such as by a K channel) (Abdoun et al., 2005) may mediate a part of ammonia uptake by the ruminal epithelium is supported by the observation of a rise in $I_{\mathrm{sc}}$ of similar magnitude after increasing mucosal ammonia from 0 to $30 \mathrm{mM}$.

The fact that the permeability of the ruminal membrane for $\mathrm{NH}_{3}$ is about 175 times as high as for $\mathrm{NH}_{4}{ }^{+}$may lead to the incorrect assumption that it is 'negligible'. This is misleading, however, since the amount of ammonia absorbed in the ionic form is considerable due to the low concentration of $\mathrm{NH}_{3}$ in relationship to $\mathrm{NH}_{4}{ }^{+}$at physiological levels of $\mathrm{pH}$. At neutral $\mathrm{pH}$, and a total concentration of $30 \mathrm{mmoll}^{-1}$ ammonia, only $0.27 \mathrm{mmoll}^{-1}$ is in the form of $\mathrm{NH}_{3}$ so that even if the permeability for $\mathrm{NH}_{4}{ }^{+}$is 175 times lower than that of $\mathrm{NH}_{3}$, the number of ions available for permeation is higher by a factor of 110 . This means that for every mmol crossing the membrane as $\mathrm{NH}_{3}, 110 / 175=0.63 \mathrm{mmol}$ or about $40 \%(=0.63 / 1.63)$ of the total amount of ammonia that is transported will be transported as $\mathrm{NH}_{4}{ }^{+}$. At a slightly acidic $\mathrm{pH}$ of $6.4\left(\mathrm{C}\left(\mathrm{NH}_{3}\right)=0.07 \mathrm{mmoll}^{-1}\right)$, the concentration of $\mathrm{NH}_{4}{ }^{+}\left(29.93 \mathrm{mmoll}^{-1}\right)$ exceeds that of $\mathrm{NH}_{3}$ by a factor of 428, and transport of $\mathrm{NH}_{4}^{+}$will be greater than that of $\mathrm{NH}_{3}$ by a factor of 428/ $175=2.44$. Thus, at $\mathrm{pH} 6.4$, over $70 \%(=2.44 / 3.44)$ of total ammonia will be absorbed as $\mathrm{NH}_{4}{ }^{+}$. Conversely, at a $\mathrm{pH}$ of $7.4\left(\mathrm{C}\left(\mathrm{NH}_{3}\right)=0.68 \mathrm{mmoll}^{-1}\right)$, the concentration of $\mathrm{NH}_{4}{ }^{+}\left(29.32 \mathrm{mmoll}^{-1}\right)$ is only 43 times as high as that of $\mathrm{NH}_{3}$, and transport of $\mathrm{NH}_{3}$ will predominate by a factor of $175 / 43=4$ and $80 \%$ of total ammonia transport will occur in the form of $\mathrm{NH}_{3}$. As to be expected from these calculations, the ruminal $\mathrm{pH}$ determines relative amounts of $\mathrm{NH}_{3}$ and $\mathrm{NH}_{4}{ }^{+}$entering the cytsol and modifying $\mathrm{Na}$ transport via the apical sodiumhydrogen exchanger (NHE) (see below and Abdoun et al. (2005)).

\section{Effect of electrical gradients on ammonia absorption}

The above-mentioned reports clearly demonstrate transepithelial movement of $\mathrm{NH}_{4}{ }^{+}$ions. Since this form of ammonia is charged, its flux rate across the epithelium should be determined not only by the chemical, but also by the electrical gradient. Similar observations have been made in other tight epithelia such as the bladder, in which Schwartz and Tripolone (1983) reported a significant increase in the serosal to mucosal and a decrease in the mucosal to serosal ammonia flux after application of $+50 \mathrm{mV}$ to the serosal side (mucosal side considered ground), while the opposite changes occurred when the voltage was clamped to $-50 \mathrm{mV}$. In the ruminal epithelium of sheep, ammonia fluxes from the mucosal to the serosal side were significantly higher when the transepithelial potential difference, $\mathrm{Pd}_{\mathrm{t}}$, was clamped to 
$-25 \mathrm{mV}$ (polarity on the serosal side) compared to those measured at a potential difference of $+25 \mathrm{mV}$ (Bödeker and Kemkowski, 1996). Recent studies from our laboratory support the assumption of $\mathrm{NH}_{4}{ }^{+}$flux across the apical membrane through a $\mathrm{K}$ channel (Abdoun et al., 2005) driven by the potential difference of the apical membrane $\left(\mathrm{Pd}_{\mathrm{a}}\right)$. Lang and Martens (1999) have shown that the change of $\mathrm{Pd}_{t}$ by $25 \mathrm{mV}$ caused alteration of $\mathrm{Pd}_{\mathrm{a}}$ of some $15 \mathrm{mV}$. The applied $\mathrm{Pd}_{\mathrm{t}}$ of $+25 \mathrm{mV}$ in the studies of Bödeker and Kemkowski (1996) depolarizes $\mathrm{Pd}_{\mathrm{a}}$ by some $15 \mathrm{mV}$ and consequently reduces $\mathrm{NH}_{4}{ }^{+}$uptake due to the diminished electrical driving force. By contrast, a $\mathrm{Pd}_{\mathrm{t}}$ of $-25 \mathrm{mV}$ enhances $\mathrm{NH}_{4}{ }^{+}$fluxes corresponding to the increase of $\mathrm{Pd}_{\mathrm{a}}$. It is worthwhile mentioning that the flow of $\mathrm{NH}_{4}{ }^{+}$through the luminal $\mathrm{K}$ channel exhibits competitive interactions with luminal K (Abdoun et al., 2005). Hence, $\mathrm{NH}_{4}{ }^{+}$absorption could be reduced at a low ruminal $\mathrm{pH}(<6.4)$ and high $\mathrm{K}$ concentration and probably vice versa.

\section{Effect of short-chain fatty acids (SCFA) and $\mathrm{CO}_{2} / \mathrm{HCO}_{3}{ }^{-}$on ammonia absorption}

In the short term, absorption of ammonia depends mainly on the concentration of $\mathrm{NH}_{3}$ near the epithelium. The SCFA and the $\mathrm{CO}_{2} / \mathrm{HCO}_{3}{ }^{-}$in the rumen can modulate this dependency leading to an increase in ammonia absorption (Bödeker et al., 1992a, b; Remond et al., 1993b). Several suggestions have been made concerning the action of these two variables (Fig. 2). Bödeker et al. (1992b) suggested that the interaction between SCFA and ammonia may occur just underneath the apical membrane of the epithelial cells. Since the $\mathrm{pH}$ inside these cells is close to 7, the SCFA absorbed in their nonionized form will dissociate and release protons, which can be used to form $\mathrm{NH}_{4}{ }^{+}$from the absorbed $\mathrm{NH}_{3}$. This process would result in a decrease in the intracellular $\mathrm{NH}_{3}$ concentration and thereby favor its absorption. Likewise, the intracellular release of $\mathrm{HCO}_{3}{ }^{-}$and $\mathrm{H}^{+}$from $\mathrm{CO}_{2}$ and $\mathrm{H}_{2} \mathrm{O}$ by the action of carbonic anhydrase could serve as a proton source for $\mathrm{NH}_{4}{ }^{+}$formation, since the inhibition of carbonic anhydrase reduces the ammonia flux across rumen mucosa in vitro (Bödeker et al., 1992a). The same authors also speculated about the passage of both SCFA ${ }^{-}$ and $\mathrm{HCO}_{3}{ }^{-}$ions across the basolateral cell membrane in conjunction with $\mathrm{NH}_{4}{ }^{+}$, allowing electroneutral exit of all three compounds against an adverse electrical potential difference (Fig. 2).

The importance of bicarbonate in stimulating $\mathrm{NH}_{3}$ absorption has also been demonstrated in monogastric animals (Wrong, 1978; Cohen et al., 1988). They suggested that colonic $\mathrm{HCO}_{3}{ }^{-}$secretion titrates luminal $\mathrm{NH}_{4}{ }^{+}$to $\mathrm{NH}_{3}$, permitting $\mathrm{NH}_{3}$ to diffuse from the lumen, while $\mathrm{HCO}_{3}{ }^{-}$is titrated to carbon dioxide which also diffuses from the lumen. Because $\mathrm{HCO}_{3}{ }^{-}$is secreted into the rumen via anion exchange (Gäbel et al., 2002), the

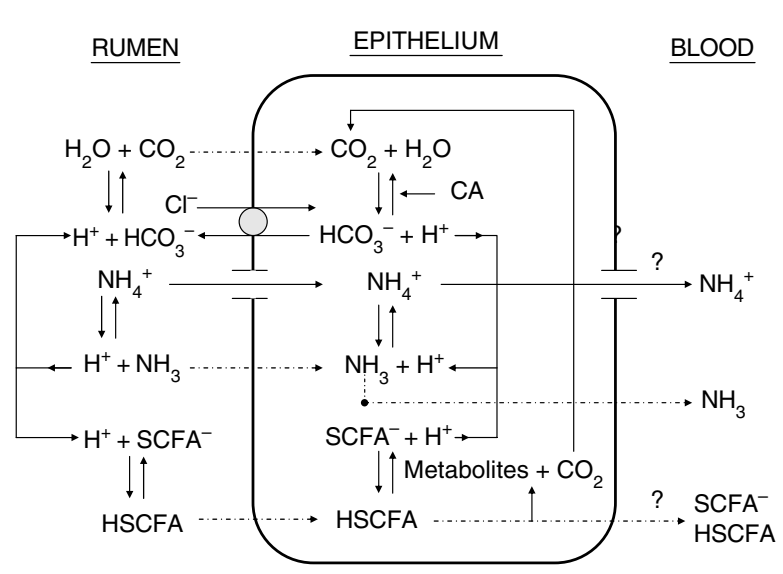

Fig. 2. Scheme of pathways of $\mathrm{NH}_{3}$ and $\mathrm{NH}_{4}{ }^{+}$across the rumen epithelium and modulation by $\mathrm{CO}_{2} / \mathrm{HCO}_{3}{ }^{-}$and SCFA. The luminal uptake of $\mathrm{NH}_{4}{ }^{+}$and $\mathrm{NH}_{3}$ is mediated by a putative $\mathrm{K}$ channel and by diffusion, respectively. The relative transport rates of both forms depend on the ruminal $\mathrm{pH}$ and the concentration of protons just above the luminal membrane. Availability of protons can be reduced by reaction with secreted $\mathrm{HCO}_{3}{ }^{-}\left(\mathrm{H}^{+}+\mathrm{HCO}_{3}{ }^{-} \leftrightarrow \mathrm{H}_{2} \mathrm{O}+\mathrm{CO}_{2}\right)$ or by protonation of SCFA $\left(\mathrm{H}^{+}+\mathrm{SCFA}^{-} \leftrightarrow \mathrm{HSCFA}\right)$. In both cases, the $\mathrm{NH}_{3}$ concentration increases and hence $\mathrm{NH}_{3}$ uptake. Intracellularly $\mathrm{NH}_{3}$ will be protonated to $\mathrm{NH}_{4}{ }^{+}$by protons of dissociation of HSCFA or $\mathrm{H}_{2} \mathrm{CO}_{3}$ (catalyzed by the carboanhydrase $=\mathrm{CA}$ ). This intracellular protonation of $\mathrm{NH}_{3}$ maintains the $\mathrm{NH}_{3}$ gradient and uptake across the luminal membrane. The exit of both forms of ammonia across the basolateral membrane is not clear. Modified from Bödeker et al. $(1992 \mathrm{a}, \mathrm{b})$.

demonstrated negative effect of an inhibition of carbonic anhydrase on ammonia transport by Bödeker et al. (1992a) can be explained by a combination of two factors: reduced intracellular titration of $\mathrm{NH}_{3}$ to $\mathrm{NH}_{4}{ }^{+}$, as mentioned above, and reduced luminal titration of $\mathrm{NH}_{4}{ }^{+}$ to $\mathrm{NH}_{3}$.

The effects of SCFA and $\mathrm{CO}_{2}$ on ammonia absorption may also be explained by their action on the subepithelial blood flow (Dobson, 1979) and irrigated capillary surface area (Thorlacius, 1972). However, Remond et al. (1993b) observed that when butyric acid was supplied to the rumen contents or when $\mathrm{CO}_{2}$ was blown in, the increase in ammonia flux across the rumen wall was always lower than the increase in ruminal blood flow produced by either of the two treatments.

\section{Ammonia transporting proteins}

The available data about ammonia transport across the rumen epithelium support the assumption of $\mathrm{NH}_{4}{ }^{+}$ transport via an apical $\mathrm{K}$ channel und diffusion of lipophilic $\mathrm{NH}_{3}$ through the membranes of the epithelium. In contrast to the kidney, where transport of ammonia takes place against a concentration gradient and thus, has to be coupled to transport of other ions, ruminal ammonia 
transport is passive and can utilize the pronounced gradient for ammonium across the tissue.

Despite this, a possible role for other membrane proteins known to facilitate transport of ammonia should be discussed. Thus, a role for the $\mathrm{Na}^{+} / \mathrm{H}^{+}$ exchanger (NHE3) in the transport of ammonia has been suggested (Nagami, 1988; Karim et al., 2005; Cermak et al., 2002). Although the rumen is known to express NHE3 (Etschmann et al., 2006), stimulation of $\mathrm{Na}$ transport by $\mathrm{NH}_{4}{ }^{+}$as found in the rumen does not fit this model (Abdoun et al., 2005) and appears to play no role in this tissue. Transport of ammonia can also take place via $\mathrm{K}^{+} / \mathrm{H}^{+}\left(\mathrm{NH}_{4}{ }^{+}\right)$exchange (Amlal and Soleimani, 1997; Karim et al., 2005), but there is no evidence for an exchanger of this type in the rumen (Schweigel and Martens, 2003).

In the kidney, substitution of $\mathrm{NH}_{4}{ }^{+}$for $\mathrm{K}^{+}$in $\mathrm{Na}-\mathrm{K}-2 \mathrm{Cl}$ accounts for the major fraction of ammonia transport in the thick ascending limb of Henle's loop (Karim et al., 2005). In the rumen, bumetanide and furosemide do not show effects on $\mathrm{Na}$ transport (Martens et al., 1988; Martens et al., 1991). It should also be noted that amiloride blocks stimulation of $\mathrm{Na}$ transport by $\mathrm{NH}_{4}{ }^{+}$at acidic pH (Abdoun et al., 2005), speaking against a role for $\mathrm{Na}-\mathrm{K}-2 \mathrm{Cl}$. The same study shows electrogenic effects of ammonia that cannot be explained by assumption of electroneutral uptake.

A lively debate surrounds the role of the ubiquitous ammonium transporter/methylpermease/Rhesus (Amt/ $\mathrm{MEP} / \mathrm{Rh}$ ) protein family (for reviews, see Weiner (2004) and Winkler (2006)). Amt/MEP/Rh proteins exhibit a characteristic extracellular high-affinity ammonium ionbinding site adapted to the function of scavenging ammonia from a site with low concentration $(\mu \mathrm{M})$ for release at a site of higher concentration, allowing survival of microorganisms in an ammonium-depleted environment (Marini et al., 2000; Winkler, 2006). In experimental situations with application of higher concentrations of ammonia ( $>5 \mathrm{mM})$, pronounced endogenous conductances for $\mathrm{NH}_{4}{ }^{+}$(Burckhardt and Frömter, 1992) typically complicate efforts to observed specific RhBG- or RhCGmediated $\mathrm{NH}_{4} \mathrm{Cl}$-dependent transport (Mak et al., 2006; Mayer et al., 2006). However, it is possible to distinguish between the two since ammonia transport via mammalian $\mathrm{Rh}$ proteins is electroneutral and typically saturates before electrogenic transport via ionic channels begins to play a major role. Recent research indicates that $\mathrm{Rh}$ proteins facilitate dissociation of $\mathrm{NH}_{4}{ }^{+}$at the channel mouth, so that uncharged $\mathrm{NH}_{3}$ and not $\mathrm{NH}_{4}{ }^{+}$is transported into the cytosol (Khademi et al., 2004; Winkler, 2006). Both exchange of $\mathrm{NH}_{4}{ }^{+}$for $\mathrm{H}^{+}$(Mak et al., 2006) and conductance for $\mathrm{NH}_{3}$ (Winkler, 2006) should inhibit, and not stimulate, Na transport via NHE as observed in the rumen at acidic $\mathrm{pH}$ values (Abdoun et al., 2005).

For the reasons outlined above, Rh proteins do not appear to be suitable candidates to explain $\mathrm{NH}_{4}{ }^{+}$ efflux from the rumen. However, the demonstration of ammonia transporter proteins $\mathrm{Rh} \mathrm{B}$ and $\mathrm{Rh} \mathrm{C}$ in the intestine of the mouse (Handlogten et al., 2005) raises the question whether these proteins may play a role in the regulation of $\mathrm{NH}_{3}$ transport across the ruminal wall, and encourages corresponding studies in the rumen epithelium.

\section{Ammonia metabolism in the rumen mucosa}

The ability of the rumen mucosa to metabolise ammonia to glutamic acid by the use of $\alpha$-ketoglutaric acid has been demonstrated by McLaren et al. (1961) and by Hoshino et al. (1966). The presence in rumen mucosa of glutamate-oxalacetate transaminase was reported by Chalupa et al. (1970a); however, the nature of this synthesis reaction was reported to be reductive desamination rather than transamination, and NADH-glutamate dehydrogenase represented the major system for glutamate synthesis from ammonia in rumen mucosa (Chalupa et al., 1970b).

More recently (Bödeker et al., 1992b) reported that 54\% of the ammonia taken up by the sheep rumen mucosa from the mucosal solution was not accounted for in the serosal solution in experiments performed during summer, whereas in tissues from sheep slaughtered in winter mucosal disappearance and serosal appearance of ammonia were equal. Moreover, we have reported a higher mucosal disappearance and a lower serosal appearance rate of ammonia across the isolated rumen epithelium of concentrate-fed sheep compared to those fed solely on hay (Abdoun et al., 2003). The gap between disappearance and appearance of ammonia can be explained by diet-dependent detoxification of ammonia in the epithelium, which indeed has been observed by Nocek et al. (1980). It has been suggested by these authors that such a mechanism would be a useful adaptation to variable intake of nitrogen and hence, different ammonia concentrations and absorption rates.

\section{Effects of ammonia on ruminal transport mechanisms}

In our studies with isolated rumen epithelium, we have shown that increasing the luminal (mucosal) ammonia concentration elevated the short-circuit current $\left(I_{\mathrm{sc}}\right)$ and the conductance $\left(G_{\mathrm{t}}\right)$ across the rumen epithelium in sheep (Abdoun et al., 2006). Furthermore, we reported an inhibitory effect of luminal ammonia on the electroneutral $\mathrm{Na}$ transport via $\mathrm{Na}^{+} / \mathrm{H}$ exchange (NHE) across the rumen epithelium of hay-fed sheep at $\mathrm{pH} 7.4$, which is completely abolished at $30 \mathrm{mM}$. In contrast, at $\mathrm{pH} 6.4$ we reported a stimulatory effect of luminal ammonia on $\mathrm{Na}$ transport via NHE (Abdoun et al., 2005).

The $\mathrm{pH}$-dependent inversion of the effect of mucosal ammonia on NHE can easily be explained by the 
predominantly absorbed form of ammonia. At a $\mathrm{pH} 7.4$, ammonia is mostly transported as $\mathrm{NH}_{3}$, which diffuses into the cytosol, binds $\mathrm{H}^{+}$and reduces proton availability for NHE. Conversely, at a $\mathrm{pH}$ of 6.4 , concentration and influx of $\mathrm{NH}_{3}$ are extremely low, and uptake of $\mathrm{NH}_{4}{ }^{+}$ occurs through the apical $\mathrm{K}$ channel with subsequent dissociation and release of $\mathrm{H}^{+}$in the more alkalic cytosol, thus stimulating NHE activity and Na transport. It should be emphasized that the stimulatory effect of ammonia on $\mathrm{Na}$ transport might be of significance in vivo, because the physiological $\mathrm{pH}$ is some 6.5 or even lower in high producing cows.

Physiologically, this ammonia-dependent stimulated $\mathrm{Na}$ absorption should help to restore osmotic pressure in the ruminal fluid after a meal. Hypertonic ruminal fluid increases water influx into the rumen (Dobson et al., 1976), decreases salivary flow (Warner and Stacy, 1977), food intake (Carter and Grovum, 1990) and SCFA absorption (Bennink et al., 1978), and thus, ammoniastimulated $\mathrm{Na}$ absorption may be of practical importance for all feeding conditions with rapid breakdown of protein. Interestingly, ammonia has been shown to stimulate $\mathrm{Na}$ flux across the rumen epithelium in concentrate-fed and urea-fed sheep even at a relatively high luminal pH of 7.4 (Abdoun et al., 2003), a pH value at which ammonia inhibits $\mathrm{Na}$ fluxes across the rumen of hay-fed animals. Note that this difference reflects a shift in the relative permeabilities of the rumen for $\mathrm{NH}_{3}$ and $\mathrm{NH}_{4}{ }^{+}$and that this shift cannot be explained by an increase in the surface area of the tissue (e.g. by growth of papillae). However, at this point, it is not clear if the permeability of the membrane for $\mathrm{NH}_{3}$ is decreased (for instance, by changes in thickness or lipid raft composition (Kikeri et al., 1989; Singh et al., 1995)) or if the relative permeability of the membrane for $\mathrm{NH}_{4}{ }^{+}$is increased (upregulation of the activity or expression of an ammonium transporting protein).

It has been known for some time that ammonia inhibits Mg absorption (Martens and Rayssiguier, 1980; Care et al., 1984) and urea secretion (v. Engelhardt et al., 1978; Remond et al., 1993b) across the rumen epithelium. Both the depolarization of the apical membrane by influx of $\mathrm{NH}_{4}{ }^{+}$and the change of $\mathrm{pH}$ (mediated primarily by influx of $\mathrm{NH}_{3}$ at neutral $\mathrm{pH}$ in non-adapted animals) should contribute to this effect (Martens and Schweigel, 2000). The negative effect of a sudden increase of ruminal ammonia concentration on $\mathrm{Mg}$ absorption disappeared within 3-4 days indicating mechanism(s) of adaptation (Gäbel and Martens, 1986; see review of Martens and Schweigel, 2000). The very tentative assumption that the permeability of the membrane for $\mathrm{NH}_{3}$ may be reduced by adaptational processes (Kikeri et al., 1989; Singh et al., 1995 ) is in line both with this observation, and with the previous observations concerning interaction of ammonia with $\mathrm{Na}$ uptake in adapted animals (Abdoun et al., 2003).

\section{Ammonia toxicity and ruminal $\mathrm{pH}$}

Ammonia toxicity occurred when circulating blood ammonia-N concentrations exceeded $0.57 \mathrm{mM}$ (Webb et al., 1972). Ammonia toxicity can arise from feeding urea or ammonium salts but there is no evidence of ammonia poisoning from protein feeding even when the concentration of ammonia in rumen liquor reaches values of over $142.8 \mathrm{mM}$ (Briggs et al., 1957).

Because rumen $\mathrm{pH}$ has a major impact on ammonia absorption, the incidence of ammonia toxicity is related to the $\mathrm{pH}$ of the ruminal fluid. Signs of toxicity were observed when the $\mathrm{pH}$ in the rumen was above 7.3 and the increase in peripheral blood ammonia was due to the inability of the liver to detoxify the increased quantity of ammonia arising from the increased rate of absorption at high pH (Coombe et al., 1960; Hogan, 1961; Ortolani et al., 2000). In addition, it was concluded that only non-ionized ammonia molecules were able to penetrate the ruminal wall proportional to their concentration, a correlation which was found to be correct for $\mathrm{pH}$ 6.9-7.5 but not from pH 6.75 to 6.9 (Gärtner and v. Engelhardt, 1964). As mentioned above, ammonia is mostly absorbed in the form of $\mathrm{NH}_{4}{ }^{+}$at $\mathrm{pH}$ 6.4, while the uptake of $\mathrm{NH}_{3}$ exceeded that of $\mathrm{NH}_{4}{ }^{+}$by a factor of 4 at $\mathrm{pH} 7.4$ (Abdoun et al., 2005). However, due to the low permeability of the membrane for the charged ion, ammonia as $\mathrm{NH}_{4}{ }^{+}$is trapped in the rumen at low $\mathrm{pH}$ and saturation effects within the ruminal proteins responsible for facilitated diffusion, such as within the multi-ion pore of channels selective for potassium, should limit the uptake of ammonia via this route (Hille and Schwarz, 1978; Hille, 2001; Abdoun et al., 2005). Conversely, the route via lipid diffusion does not saturate. Accordingly, risk of ammonia toxicity may rise with ruminal ammonia concentration, but only if ruminal $\mathrm{pH}$ reaches values of over 7.3 (Coombe et al., 1960; Hogan, 1961; Ortolani et al., 2000).

It has been shown that when ammonium acetate was given, rumen $\mathrm{pH}$ remained fairly stable and rumen ammonia-N concentrations greater than $140 \mathrm{mM}$ were tolerated without toxic manifestations. However, when urea was administered, the $\mathrm{pH}$ increased rapidly and rumen ammonia- $\mathrm{N}$ concentrations less than $70 \mathrm{mM}$ resulted in appreciable ammonia absorption and as little as $7 \mathrm{mM}$ was frequently highly toxic to sheep that had been kept on a diet of poor quality grass hay previous to dosing (Webb et al., 1972). In this context, it is important to remember that at constant concentration of total ammonia, the concentration of $\mathrm{NH}_{3}$ rises by a factor of 3 when pH rises from 6.5 to 7 , by a factor of 10 when $\mathrm{pH}$ rises from 6.5 to 7.5 , and by a factor of 20 if $\mathrm{pH}$ increases to 7.8. Thus, ruminal $\mathrm{pH}$ is a very critical factor in determining the toxicity of ammonia, leading to an increased concentration of ammonia in portal vein blood overloading the liver and causing a rise in the ammonia concentration of circulating peripheral 
blood (Coombe et al., 1960; Hogan, 1961; Ortolani et al., 2000).

\section{Ammonia metabolism in the liver}

Measurements of net portal drained viscera (PDV) ammonia-N flux over a wide range of nitrogen intakes and different diets (Fig. 3A) suggest that ammonia-N absorption by PDV is not closely correlated with dietary nitrogen supply.

Net PDV ammonia nitrogen flux is, however, highly correlated with the digestible nitrogen intake (Reynolds et al., 1991, 1992a). Quantities of ammonia absorbed by PDV seem to be determined not only by intake of digestible nitrogen but also by the nature of carbohydrate and protein consumed.

All ammonia absorbed by PDV is subsequently removed by the liver so that splanchnic flux is very low or negative (Chalmers et al., 1971). Hepatic removal of ammonia and conversion to urea has been proposed to involve concomitant catabolism of amino acids, to provide via aspartate the other $\mathrm{N}$ atom in urea (Parker et al., 1995). However, the relationship between hepatic removal of ammonia and amino acids is described as weak (Lapierre et al., 2005). Furthermore, in sheep infused with ammonium bicarbonate, there was only a limited requirement for additional amino acid catabolism to support the extra urea synthesis (Milano et al., 2000). In addition, the utilization of ammonia for urea synthesis in hepatocytes isolated from sheep liver was stimulated by propionate (Garwacki et al., 1990).

Ammonia removed by the liver is converted into urea or glutamine. Half of the extra ammonia removed by the liver was, apparently, utilized by periportal glutamate dehydrogenase and aspartate aminotransferase for sequential glutamate and aspartate synthesis and converted to urea as the 2-amino moiety of aspartate (Milano et al., 2000). Any ammonia which escapes conversion to urea in periportal hepatocytes is converted to glutamine in perivenous hepatocytes. The amide- $\mathrm{N}$ of glutamine is then removed and metabolized to urea by periportal hepatocytes during subsequent passages through the liver (Hussinger et al., 1992).

Ammonia absorbed across the PDV is derived in part from urea transferred into the gut lumen, and a substantial cycling of urea and ammonia between the PDV and liver occurs in ruminants (Huntington, 1986). In growing cattle fed diets high in rumen soluble nitrogen, excessive ammonia absorption has been associated with increased net removal of amino acids by the liver (Huntington, 1989; Reynolds et al., 1991). This response has been attributed to an increase in urea cycle requirements for cytosolic aspartate and glutamate, which cannot be met by mitochondrial capture of ammonia as glutamate (Reynolds, 1992).

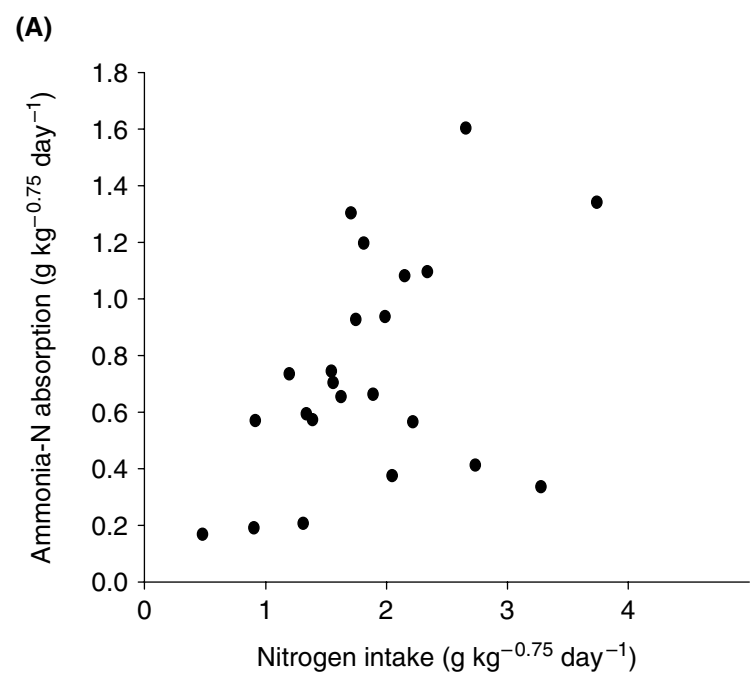

(B)

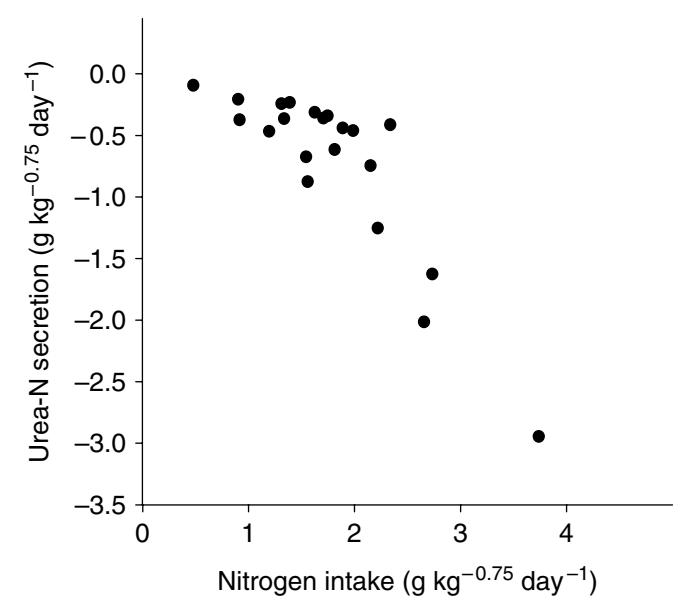

Fig. 3. The relationship between nitrogen intake $\left(\mathrm{g} \mathrm{kg}^{-0.75}\right.$ day $\left.^{-1}\right)$ and the transport rates of ammonia nitrogen (absorption) and urea nitrogen (secretion) across the digestive tract $\left(\mathrm{g} \mathrm{kg}^{-0.75} \mathrm{day}^{-1}\right)$. Each point represents animal means from individual experiments. There is evidently no close correlation between the nitrogen intake and ammonia absorption from the digestive tract. Calculation of a statistical correlation requires a careful metaanalysis of the data, which was beyond the scope of this review. However, it is quite evident that urea recycling is increased with nitrogen intake. Data are from the experiments of Huntington and Prior (1983), Harmon et al. (1993), Reynolds et al. (1992b), Guerino et al. (1991), Reynolds and Tyrrell (1991), Eisemann and Nienaber (1990), Reynolds and Huntington (1988), Sniffen and Jacobson (1974), Wolf et al. (1972), Wilton et al. (1988), Fitch et al. (1989), Huntington (1989), Maltby et al. (1991), Maltby et al. (1993a), Maltby et al. (1993b) and Reynolds et al. (1991).

Over a wide range of portal ammonia concentrations on a variety of different diets, the liver is able to extract almost $100 \%$ of the portal ammonia (Parker et al., 1995). The upper limit of the capacity of ruminant liver to remove ammonia is $1.2-1.5 \mu \mathrm{mol} \mathrm{min}{ }^{-1} \mathrm{~g}^{-1}$ 
(Linzell et al., 1971; Symonds et al., 1981; Orzechowski et al., 1987), which is higher than the range of $0.2-0.8 \mu \mathrm{mol} \mathrm{min}{ }^{-1} \mathrm{~g}^{-1}$ of flow of ammonia to the liver over a wide variety of nutritional regimens. Therefore, the capacity of ruminant hepatocytes to detoxify ammonia directly to urea appears to be well adapted to large changes in portal ammonia concentration and is only exceeded when ammonia loads on the liver are abnormal (Symonds et al., 1981; Fernandez et al., 1990).

Ammonia is extremely toxic in non-hepatic tissues and causes changes in cerebral metabolism by affecting the glutamate transporter (GLAST) and thus reducing the capacity of astrocytes for reuptake of glutamate (Chan et al., 2000), which results in tetany and death when circulating ammonia concentrations exceed $0.7 \mathrm{mM}$ (Symonds et al., 1981). Most investigators have reported physiological arterial ammonia concentrations in the $0.1 \mathrm{mM}$ range using specific enzyme assays which follow the reaction with glutamate dehydrogenase (Bergmeyer and Beutler, 1985).

\section{Recycling of urea}

Since the work of Simmonet et al. (1957), numerous studies have shown that blood urea can cross the rumen epithelium. This process is nutritionally beneficial for ruminants, since the bacteria present in the rumen are able to use urea nitrogen for synthesis of proteins, the amino acid of which is subsequently available for postruminal absorption. The quantities of nitrogen recycled vary widely, and may account for up to $25 \%$ of the nitrogen ingested (Obara et al., 1991) or up to $90 \%$ of urea turnover (see review of Harmeyer and Martens, 1980; Marini et al., 2006). However, the absolute amount of recycled urea appears to be relative constant (Marini et al., 2006).

Removal of absorbed ammonia plus excess amino acids and their conversion to urea by the liver represents a major cross-road in terms of whole body $\mathrm{N}$ exchange. At this metabolic junction, hepatic urea genesis represents 0.81 of digested N (Lapierre et al., 2005). Therefore, a large part of this synthesized urea must be cycled rather than lost in urine. The quantities of nitrogen recycled in this way vary widely, and may account for up to $90 \%$ of urea turnover (see review of Harmeyer and Martens, 1980; Marini et al., 2006). There is a negative venous-arterial flux of urea across the PDV. This denotes a net transfer of urea from the blood into the gut lumen. Net PDV urea N flux is clearly correlated with dietary nitrogen intake (Fig. 3B). On average, 0.47 of hepatic urea genesis, the equivalent of 0.34 of the digested $\mathrm{N}$ is returned to the gut via the PDV (Lapierre et al., 2005). This $\mathrm{N}$ recycling represents an important fraction of the total flow of $\mathrm{N}$ through the digestive tract.
In practice, the true contribution of urea to gut $\mathrm{N}$ inflow should be even higher as the portal flux measurements do not include saliva flow. This latter input varies with the type of diet given and represents 0.22 of total gut entry rate with a concentrate-based ration, but 0.47 with a forage-based diet (Huntington, 1989). Such recycling will be effective only if the urea returned to the gut is used for anabolic purposes, i.e. as a precursor for microbial protein synthesis. The magnitude of this contribution will depend, among other things, on the site of return to the gut, as urea which enters the rumen is more likely to act as precursor- $\mathrm{N}$ for microbial protein synthesis with subsequent digestion and absorption across the small intestine. In contrast, while urea returned to the hind gut can also be used for microbial protein synthesis, these proteins will not be absorbed. The use of urea-N to support microbial protein synthesis within the small intestine and to supply amino acids to the host animals has recently been of considerable interest in non-ruminants (including pigs and human; Metges et al., 1999; Torrallardona et al., 2003). In ruminants, however, the contribution from this site is probably minor compared to that from the rumen (Lapierre and Lobley, 2001). In dairy cows, based on $\left[{ }^{15} \mathrm{~N}\right]$ urea kinetics, urea returned to the gut represented 0.67 of whole body urea production. This value is higher than the average obtained from PDV flow and includes the contribution from saliva. Of this return, 0.54 was used for anabolic purposes, 0.38 was reabsorbed as ammonia and returned to the urea cycle, and 0.08 was lost in the faeces (Lapierre et al., 2004).

\section{Ruminal urea transport}

Diffusion of urea through the rumen epithelium has been demonstrated many years ago in vivo and in vitro (Gärtner et al., 1961; v. Engelhardt und Nickel, 1965). The work of Houpt and Houpt (1968) showed that urea transfer across the rumen wall was linearly related to the rumen-blood concentration gradient, and it has been generally accepted that urea crosses the rumen epithelium by simple diffusion. Intraruminal hydrolysis of urea by bacterial urease therefore facilitates the movement of urea through the rumen wall by maintaining concentration gradient favorable to diffusion. Hence, it has been shown that the inhibition of urease activity in the rumen causes a decrease in the transepithelial flux of urea (Houpt and Houpt, 1968; Remond et al., 1993b). In addition, the urea flux is dependent on the permeability of the epithelium. Since damage to the structure of the stratum corneum results in a marked increase in urea transport, urea diffusion seems to be strongly limited by the low permeability of this epithelial layer (Houpt and Houpt, 1968). 


\section{Factors influencing urea recycling/flux}

\section{Stimulation}

When the feed is supplemented with a rapidly fermentable energy source (sucrose, extruded barley), the daily flux of urea across the rumen wall can be increased (Kennedy and Milligan, 1980; Reynolds and Huntington, 1988; Theurer et al., 2002) or even doubled (Obara et al., 1991; Norton et al., 1982). As the blood urea level decreases when these energy supplements are added, the increase in urea flux must be mainly due to modified epithelial surface area and/ or permeability, in response to intraruminal volatile fatty acids (VFAs) levels or $\mathrm{CO}_{2}$ production. VFA and $\mathrm{CO}_{2}$ production indicates fermentation in the rumen, which can only be maintained at optimal ammonia concentration for microbial growth (Satter and Slyter, 1974). Urea influx into the rumen significantly contributes to sustain sufficient ammonia concentration for optimal fermentation. Vice versa, reflux of urea was reduced in unfed sheep (Harmeyer and Martens, 1980).

Indeed, the transfer of urea across the rumen wall varies in the course of a feeding cycle (Remond et al., 1993a), and so is evidently governed by a system of short-term regulation. Bubbling $\mathrm{CO}_{2}$ in the rumen significantly increases urea flux across the rumen wall (Thorlacius et al., 1971; v. Engelhardt et al., 1978; Remond et al., 1993b). Likewise, increasing the butyric acid concentration in an isolated pouch of the rumen favors urea transfer (v. Engelhardt et al., 1978). The action of these two intraruminal factors does not involve modifications to the ruminal urease activity (Thorlacius et al., 1971; Remond et al., 1993b). Although $\mathrm{CO}_{2}$ and butyric acid stimulate sub-epithelial blood flow (Dobson, 1984), the permeability of the capillary walls to urea is too low for the blood flow to affect urea diffusion (Landis and Pappenheimer, 1963). In addition, according to the results of Dobson et al. (1971), urea clearance seems virtually independent of blood flow.

\section{Inhibition}

Increasing intraruminal ammonia concentration decreases the urea flux across the rumen wall (v. Engelhardt et al., 1978; Remond et al., 1993b). According to Remond et al. (1993b), ammonia absorption may be responsible for reducing urea flux. The effect of ammonia on urease activity is long term (Cheng and Wallace, 1979) rather than short term, and the mechanism by which ammonia regulates the transepithelial flux of urea during short-term variations is not yet known.

\section{Further observations}

Other factors may also be involved in the regulation of transepithelial urea flux. Increasing osmotic pressure in an isolated pouch of the rumen with mannitol (Houpt, 1970) stimulates urea transfer. However, Remond et al. (1993b) raised the intraruminal osmotic pressure with $\mathrm{NaCl}$ injections, and observed no effect on urea flux.

Hormonal regulation of the urea flux has also been considered. According to Houpt (1970), vasopressin may modify the permeability of the rumen wall to urea, which has recently been shown to increase urea transport in MDCK monolayers (Potter et al., 2006). However, Thorlacius et al. (1971) observed no modification of the urea clearance in response to vasopressin injection. The work of Harrop and Phillipson (1970) and Remond et al. (1993b) also suggests that gastrin might play a role in the regulation of the urea flux across the rumen wall. Generally, the effects of hormones and second messengers on transport mechanisms of the rumen epithelium have hardly been studied and are not well understood (see the literature in Schweigel et al., 2005).

\section{Urea transport proteins and tentative model of ruminal urea transport}

Previously, movement of urea across biological membranes was considered to occur by lipid phase diffusion. However, the urea permeability of erythrocyte membranes and of certain plasma membranes in the terminal part of the kidney collecting duct were found to be much higher than could be explained by passive lipid diffusion alone (Marsh and Knepper, 1992). This inconsistency prompted the notion that urea crosses biological membranes by a carrier-mediated mechanism (urea transporter: UT). Recent studies have clearly shown that UT mRNA and protein are present in the rumen and colon epithelium of sheep (Ritzhaupt et al., 1997, 1998). Protein corresponding to UT-B has been reported in rumen of cattle (Marini and Van Amburgh, 2003) and the entire gastrointestinal tract of sheep, while bands corresponding to UT-A could only be found in sheep duodenum (Marini et al., 2004; Marini et al., 2006). The structure of the bovine UT-B gene has been determined (Stewart et al., 2005). This study also demonstrates that in analogy to sheep, only UT-B, but not UT-A, is expressed by the bovine rumen.

In a recent study in our laboratory, the serosal to mucosal urea fluxes across the isolated rumen epithelium did not show any correlation to the variation in tissue conductance $\left(G_{\mathrm{t}}\right)$. This means that the shunt pathway does not play a major role in urea transport across the rumen epithelium, and that transcellular urea flux predominates. In addition, the concentration-dependent flux density $(J / A \cdot C)$ of urea over the membrane was 
found to be considerably lower than the corresponding values for the flux of $\mathrm{NH}_{3}$ from our previous study (Abdoun et al., 2005). These data allow further deliberations. As stated above, our lack of knowledge about the precise dimensions of the ruminal epithelial barrier do not permit an estimate for the permeability coefficient of urea. However, if the permeability is given by $P=J / A \cdot C$ ( $J=$ flux, $\mathrm{A}=$ area and $\mathrm{C}=$ concentration), the permeability ratio $P\left(\mathrm{NH}_{3}\right) / P($ Urea $)$ between two substances such as $\mathrm{NH}_{3}$ and urea can be calculated with reasonable accuracy since the unknown eithelial area is cancelled out of the equation, and compared to the same quotients from experiments performed on artificial lipid bilayers (Lande et al., 1995). The permeability ratio $P\left(\mathrm{NH}_{3}\right) / P($ Urea $)$ of ruminal epithelium was found to be two orders of magnitude above that of the artificial bilayer systems, which can be taken as further piece of evidence suggesting that assumption of simple diffusion is not sufficient to explain the observations.

This conclusion is consistent with recent studies about the localization of the proposed urea transporter in the rumen epithelium of cows. Stewart et al. (2005) demonstrated staining of urea transporter in membranes of all epithelial layers of bovine rumen with the exception of the stratum corneum.

In combination with immunolocalization studies of urea transporter proteins of Stewart et al. (2005), the physiological findings about the flux of urea across the rumen epithelium allow the proposal of a putative model of urea transport. Under in vivo conditions, urea is taken up with the urea transporter across the basolateral membrane of the stratum basale into the epithelium. The flux of urea through the different layers of the rumen epithelium is mediated via the urea transporter (Stewart et al., 2005) or via diffusion through the gap junctions (Graham and Simmons, 2004). The localization of urea transporter in the membrane of the stratum granulosum permits the extrusion of urea into the lumen. At the present time no explanation can be given, how ammonia, $\mathrm{CO}_{2}$ or SCFA change urea flux rates according to the proposed model of urea transport.

Despite these uncertainties, the improved knowledge about urea transport across the rumen epithelium allows some conclusions and suggestions for future research. It is unlikely that the activity of ruminal urease limits urea back flow, because this enzyme has a capacity which clearly exceeds the amount of urea flowing back into the rumen (Bloomfield et al., 1960). Furthermore, blood flow probably seems not to be a limiting factor. It is interesting to note that urea transport is modified by the fermentation products ammonia, $\mathrm{CO}_{2}$ and SCFA. It has been convincingly demonstrated that these fermentation products significantly influence electroneutral $\mathrm{Na}$ transport via NHE indicating changes of intracellular $\mathrm{pH}$ and availability of $\mathrm{H}^{+}$for NHE (Gäbel et al., 1991; Sehested et al., 1999; Abdoun et al., 2003, 2005). Any direct link or transfer of this knowledge to urea transport is very speculative at this time, but the shift of urea recycling to the forestomachs by increasing the intake of concentrate of an isocaloric and isonitrogenous diet (Theurer et al., 2002) in steers suggests an important effect of fermentation at least in short-term regulation of urea transport.

In conclusion, large amounts of ammonia and urea are transported per day across the rumen epithelium: ammonia is absorbed from and urea is recycled into the rumen. The present data support the assumption of absorption of $\mathrm{NH}_{3}$ by simple diffusion, which dominates at ruminal $\mathrm{pH}$ values above 7.0. At physiological $\mathrm{pH}$ values - pH 6.5 or lower - ammonia is predominantly absorbed as $\mathrm{NH}_{4}{ }^{+}$through a putative $\mathrm{K}$ channel. No data are available regarding ammonia transporting proteins. Ammonia is metabolized during the passage across the epithelium at various rates, which are probably influenced by the diet.

Urea recycling is one of the important strategies of the ruminants to use food with a low protein content and to survive under harsh feeding conditions. The flow of urea into the rumen exhibits wide variations, which are not well understood at the present time. The recent detection of the urea transporter in the rumen epithelium and the well-established in vivo and in vitro techniques for studying urea transport open up perspectives for a better understanding of the modulation of urea transport. Since interaction between fermentation products and urea transport is established in a descriptive way, future research should be directed to modulation of urea transport by VFA or $\mathrm{CO}_{2}$ for a better understanding of these effects. Still not clear are the effects of ruminal ammonia concentration on urea flux. It could be that these effects of ruminal ammonia on urea transport depends on the $\mathrm{pH}$ and/or feeding conditions as it has been demonstrated for $\mathrm{Na}$ transport (Abdoun et al., 2003, 2005).

\section{Acknowledgments}

K. Abdoun is a recipient of a scholarship of the Alexander von Humboldt Foundation (Georg-Foster). Our studies were supported by the Deutsche Forschungsgemeinschaft and the Margarete-Markus-Charity.

\section{References}

Abdoun K, Wolf K, Arndt G and Martens H (2003). Effect of ammonia on $\mathrm{Na}^{+}$transport across isolated rumen epithelium of sheep is diet dependent. British Journal of Nutrition 90: 751-758.

Abdoun K, Stumpff F, Wolf K and Martens H (2005). Modulation of electroneutral $\mathrm{Na}$ transport in sheep rumen epithelium by luminal ammonia. American Journal of Physiology, Gastrointestinal and Liver Physiology 289: G508-G520.

Abdoun K, Wolf K and Martens H (2006). Interaction between ammonia, sodium and chloride transport across the 
rumen epithelium of sheep. Small Ruminant Research 63 : 91-99.

Amlal $\mathrm{H}$ and Soleimani $\mathrm{M}$ (1997). $\mathrm{K}^{+} / \mathrm{NH}_{4}{ }^{+}$antiporter: a unique ammonium carrying transporter in the kidney inner medulla. Biochimica et Biophys Acta 1323: 319-333.

Bennink MR, Tyler TR, Ward GM and Johnson DE (1978). Ionic milieu of bovine and ovine rumen as affected by diet. Journal of Dairy Science 61: 315-323.

Bergmeyer HU and Beutler H-O (1985). In: Bergmeyer HU (ed.) Methods of Enzymatic Analysis, 3rd edn. Weinheim, Germany: VCH Publishing Group, Vol. VIII, pp. 454-461.

Blank R, Südekum K-H, Immig I and Kleinmans J (1998). Synchroner Abbau von Kohlenhydraten und Rohprotein in den Vormägen - eine neue Variable für die Rationsgestaltung? Übersichten Tierernäbrung 26: 157-188.

Bloomfield RA, Garner GB and Muhrer ME (1960). Kinetics of urea metabolism in sheep. Journal of Animal Science 19: 1248 (Abstract).

Bödeker D and Kemkowski J (1996). Participation of $\mathrm{NH}_{4}{ }^{+}$in total ammonia absorption across the rumen epithelium of sheep (Ovis aries). Comparative Biochemical Physiolog A 114: 305-310.

Bödeker D, Winkler A and Holler H (1990). Ammonia absorption from the isolated reticulo-rumen of sheep. Experimental Physiology 75: 587-795.

Bödeker D, Oppelland G and Holler H (1992a). Involvement of carbonic anhydrase in ammonia flux across rumen mucosa in vitro. Experimental Physiology 77: 517-519.

Bödeker D, Shen Y, Kemkowski J and Höller H (1992b). Influence of short-chain fatty acids on ammonia absorption across the rumen wall of sheep. Experimental Physiology 77: 369-376.

Briggs PK, Hogan JP and Reid RL (1957). Effect of volatile fatty acids, lactic acid and ammonia on rumen $\mathrm{pH}$ in sheep. Australian Journal of Agricultural Research 8: 674-690.

Bryant MP and Robinson IM (1962). Some nutritional characteristics of predominant culturable ruminal bacteria. Journal of Bacteriology 84: 605-614.

Burckhardt BC and Frömter E (1992). Pathways of $\mathrm{NH}_{3} / \mathrm{NH}_{4}{ }^{+}$ permeation across Xenopus laevis oocyte cell membrane. Pflügers Archiv: European Journal of Physiology 420: 83-86.

Care AD, Brown RC, Farrar AR and Pickard DW (1984). Magnesium absorption from the digestive tract of sheep. Quarterly Journal of Experimental Physiology 69: $577-587$.

Carter RR and Grovum WL (1990). A review of the physiological significance of hypertonic body fluids on feed intake and ruminal function: salivation, motility and microbes. Journal of Animal Science 68: 2811-2832.

Cermak R, Minck K, Lawnitzak C and Scharrer E (2002). Ammonia inhibits sodium and chloride absorption in rat distal colon. Experimental Physiology 87: 311-319.

Chalmers MI, Jaffray AE and White F (1971). Movements of ammonia following intraruminal administration of urea or casein. Proceedings of the Nutritional Society 30: $7-17$.

Chalupa WJ, Opliger CP and Lavker R (1970a). Ammonia metabolism in rumen bacteria and mucosa from sheep fed soy protein or urea. Journal of Nutrition 100: 161-169.

Chalupa WJ, Opliger CP and Lavker R (1970b). Detoxification of ammonia in sheep fed soy protein or urea. Journal of Nutrition 100: 170-176.

Chan H, Hazell AS, Desjardins P and Butterworth RF (2000). Effect of ammonia on glutamate transporter (GLAST) protein and mRNA in cultured rat cortical astrocytes. Neurochemistry International 37: 243-248.
Cheng KJ and Wallace RJ (1979). The mechanism of passage of endogenous urea through the rumen wall and the role of ureolytic epithelial bacteria in the urea flow. British Journal of Nutrition 42: 553-557.

Choe H, Sackin H and Palmer LG (2000). Permeation properties of inward-rectifier potassium channels and their molecular determinants. Journal of General Physiology 115 : 391-404.

Cohen RM, Stephenson RL and Feldman GM (1988). Bicarbonate secretion modulates ammonium absorption in rat distal colon in vivo. American Journal of Physiology 254: F657-F667.

Coombe JB, Tribe DE and Morrison JWC (1960). Some experimental observation on the toxicity of urea to sheep. Australian Journal of Agricultural Research 11: 247-256.

Cotta MA and Hespell RB (1986). Protein and amino acid metabolism of rumen bacteria. In: Milligan LP, Grovum WL and Dobson A (eds) Control of Digestion and Metabolism in Ruminants. Washington, DC: Butterworths, pp. 122-136.

Dobson A (1959). Active transport through the epithelium of the reticulo-rumen sac. Journal of Physiology 146: 235-251.

Dobson A (1979). The choice of models relating tritiated water absorption to subepithelial blood flow in the rumen of sheep. Journal of Physiology 297: 111-121.

Dobson A (1984). Blood flow and absorption from the rumen. Quarterly Journal of Experimental Physiology 69: 599-606.

Dobson A, Sellers AF and Thorlacius SO (1971). Limitation of diffusion by blood flow through bovine ruminal epithelium. American Journal of Physiology 220: 1337-1343.

Dobson A, Sellers AF and Gatewood VH (1976). Absorption and exchange of water across rumen epithelium. American Journal of Physiology 231: 1588-1594.

Eisemann JH and Nienaber JA (1990). Tissue and whole-body oxygen uptake in fed and fasted steers. British Journal of Nutrition 64: 399-411.

v. Engelhardt W and Nickel W (1965). Die Permealität der Pansenwand für Harnstoff, Antipyrin und Wasser. European Journal of Physiology 286: 57-75.

v. Engelhardt W, Hinderer S and Wipper E (1978). Factors influencing the endogenous urea-N secretion and utilization in the gastrointestinal tract. In: Osboum DF, Beever DE and Thomson DJ (eds) Ruminants Digestion and Feed Evaluation. London: Agricultural Research Council, pp. 4.1-4.12.

Etschmann B, Heipertz KS, von der Schulenburg A and Schweigel M (2006). A vH ${ }^{+}$-ATPase is present in cultured sheep ruminal epithelial cells. American Journal of Physiology Gastrointest Liver Physiology, Epub ahead of print.

Fernandez JM, Croon WJ, Tate LP and Johnson AD (1990). Subclinical ammonia toxicity in steers: effects on hepatic and portal-drained visceral flux of metabolites and regulatory hormones. Journal of Animal Science $\mathbf{6 8}$ : 419-429.

Ferreira HG, Harrison FA, Keynes RD and Nauss AH (1966a). Observations on the potential across the rumen of sheep. Journal of Physiology 187: 615-630.

Ferreira HG, Harrison FA and Keynes RD (1966b). The potential and short-circuit current across isolated rumen epithelium of the sheep. Journal of Physiology 187: 631-644.

Ferreira HG, Harrison FA, Keynes RD and Zurich L (1972). Ion transport across an isolated preparation of sheep rumen epithelium. Journal of Physiology 222: 77-93.

Fitch NA, Gill M, Lomax MA and Beever DE (1989). Nitrogen and glucose metabolism by the liver of forage- and forageconcentrate fed cattle. Proceedings of the Nutrition Society 48: 76A. 
Fuller MF and Rees PJ (1998). Nitrogen recycling in the gut Annual Review of Nutrition 18: 385-411.

Gäbel G and Martens H (1986). The effect of ammonia on magnesium metabolism in sheep. Zeitschrift für Tierphysiologie, Tierernährung und Futtermittelkunde 55: 278-287.

Gäbel G, Vogler S and Martens H (1991). Short-chain fatty acids and $\mathrm{CO}_{2}$ as regulators of $\mathrm{Na}^{+}$and $\mathrm{Cl}^{-}$absorption in isolated sheep rumen mucosa. Journal of Comparative Physiology B 161: 419-426.

Gäbel G, Aschenbach JR and Müller F (2002). Transfer of energy substrates across the ruminal epithelium: implications and limitations. Animal Health Research Reviews 3: 15-30.

Gärtner K and v. Engelhardt W (1964). Experiments concerning the resorption mechanism of ammonia through the ruminal mucosa of ruminants. Deutsche Tierärztliche Wochenschrift 71: $57-60$.

Gärtner K, Decker P and Hill H (1961). Untersuchungen über die Passage von Harnstoff und Ammoniak durch die Pansenwand von Ziegen. European Journal of Physiology 274: 281-288.

Garwacki S, Wiechetek M, Karlik W, Souffrant WB and Krawielitzki K (1990). Effect of propionate on the utilization of nitrogen from ${ }^{15} \mathrm{NH}_{4} \mathrm{Cl}$ for urea synthesis in hepatocytes isolated from sheep liver. International Journal of Biochemistry 22: 1185-1188.

Graham C and Simmons NL (2004). Functional organization of the bovine rumen epithelium. American Journal of Physiology 288: R173-R181.

Guerino F, Huntington GB and Erdman RA (1991). The net portal and hepatic flux of metabolites and oxygen consumption in growing beef steers given postruminal casein. Journal of Animal Science 69: 387-395.

Handlogten ME, Hong SP, Zhang L, Vander AW, Steinbaum ML, Campbell-Thompson $M$ and Weiner ID (2005). Expression of the ammonia transporter proteins Rh B glycoprotein and $\mathrm{Rh} \mathrm{C}$ glycoprotein in the intestinal tract. American Journal of Physiology 288: G1036-G1047.

Harmeyer J and Martens H (1980). Some aspects of urea metabolism in ruminants with particular reference to the goat. Journal of Dairy Science 63: 1707-1728.

Harmon DL, Kreikemeier KK and Gross KL (1993). Influence of addition of monensin to an alfalfa hay diet on net portal and hepatic nutrient flux in steers. Journal of Animal Science 71: 218-225.

Harrison FA, Keynes RD, Rankin JC and Zurich L (1975). The effect of ouabain on ion transport across isolated sheep rumen epithelium. Journal of Physiology 249: 669-677.

Harrop CJF and Phillipson AT (1970). The effect of diet and pentagastrin on thew influx of urea into the rumen of sheep. Proceedings of the Nutrition Society 30: 3A

Henning JP, Steyn DG and Meissner HH (1993). Effect of synchronization of energy and nitrogen supply on ruminal characteristics and microbial growth. Journal of Animal Science 71: 2516-2528.

Hille B (2001). Ion Channels of Excitable Membranes, 3rd edn. Sunderland, USA: Sinauer Associates, Inc., Chapter 15, pp. 482.

Hille B and Schwarz W (1978). Potassium channels as multi-ion single-file pores. Journal of General Physiology 72: 409-442.

Hogan JP (1961). The absorption of ammonia through the rumen of the sheep. Australian Journal of Biological Science 14: $448-460$.

Hoshino S, Sarumaru K and Morimoto K (1966). Ammonia anabolism in ruminants. Journal of Dairy Science 49 $1523-1528$.
Houpt TR (1970). Transfer of urea and ammonia to the rumen. In: Phillipson AT (ed.) Physiology of Digestion and Metabolism in the Ruminant. Newcastle-upon-Tyne, UK: Oriel Press, pp. 119-131.

Houpt TR and Houpt KA (1968). Transfer of urea nitrogen across the rumen wall. American Journal of Physiology 214: 12961303.

Hristov M and Broderick GA (1994). In vitro determinations of rumination protein degradability using $\left[{ }^{15} \mathrm{~N}\right]$ ammonia to correct for microbial nitrogen uptake. Journal of Animal Science 72: 1344-1354.

Huntington GB (1986). Uptake and transport of non protein nitrogen by the ruminant gut. Federation Proceedings 45: 2272-2276.

Huntington GB (1989). Hepatic urea synthesis and site and rate of urea removal from blood of beef steers fed alfalfa hay or a high concentrate diet. Canadian Journal of Animal Science 69: 215-223.

Huntington GB and Prior RL (1983). Digestion and absorption of nutrients by beef heifers fed a high concentrate diet. Journal of Nutrition 113: 2280-2288.

Huntington GB, Zetina EJ, Whitt JM and Potts W (1996). Effects of dietary concentrate level on nutrient absorption, liver metabolism, and urea kinetics of beef steers fed isonitrogenous and isoenergetic diets. Journal of Animal Science 74: 908-916.

Hussinger D, Lamers WH and Moorman AFM (1992). Hepatocyte heterogeneity in the metabolism of amino acids and ammonia. Enzyme 46: 72-93.

Hyden S. (1961). Observations on the absorption of inorganic ions from the reticulo-rumen of the sheep. Kungl. Lantbrukshögkolans Annaler 27: 273-285.

Kang-Meznarich JH and Broderick GA (1981). Effects of incremental urea supplementation on ruminal ammonia concentration and bacterial protein formation. Journal of Animal Science 51: 422-431.

Karim Z, Szutkowska M, Vernimmen C and Bichara M (2005). Renal handling of $\mathrm{NH}_{3} / \mathrm{NH}_{4}^{+}$: recent concepts. Nephron Physiology 101: 77-81.

Kennedy PM and Milligan LP (1980). The degradation and utilization of endogenous urea in the gastrointestinal tract of ruminants, a review. Canadian Journal of Animal Science 60: 205-221.

Kennedy PM, Early RJ, Chrispherson RJ and Milligan LP (1986). Nitrogen transformations and duodenal amino acid content in sheep given four forage diets and exposed to warm and cold ambient temperatures. Canadian Journal of Animal Science 66: 951-957.

Khademi S, O'Connell J, 3rd, Remis J, Robles-Colmenares Y, Miercke LJ and Stroud RM (2004). Mechanism of ammonia transport by $\mathrm{Amt} / \mathrm{MEP} / \mathrm{Rh}$ : structure of $\mathrm{AmtB}$ at $1.35 \mathrm{~A}$. Science 305: 1587-1594.

Kikeri D, Sun A, Zeidel ML and Hebert SC (1989). Cell membranes impermeable to $\mathrm{NH}_{3}$. Nature 339: 478480 .

Lande MB, Donovan JM and Zeidel ML (1995). The relationship between membrane fluidity and permeabilities to water, solutes, ammonia and protons. Journal of General Physiology 106: 67-84.

Landis EM and Pappenheimer JR (1963). Exchanges of substances through the capillary walls. In: Hamilton WF (ed.) Handbook of Physiology, Vol. 2, Section 2, Circulation. Washington, DC: American Physiological Society, pp. 961.

Lang I and Martens H (1999). Na transport in sheep rumen is modulated by voltage-dependent cation conductance in apical membrane. American Journal of Physiology 277: G609-G618. 
Lapierre H and Lobley GE (2001). Nitrogen recycling in the ruminant, a review. Journal of Dairy Science 84 (suppl. E): E223-E236.

Lapierre H, Ouellet DR, Berthiaume R, Girard C, Dubreuil P, Babkine $M$ and Lobley GE (2004). Effect of urea supplementation on urea kinetics and splanchnic flux of amino acids in dairy cows. Journal of Animal and Feed Sciences 13 (suppl. 1): 319-322.

Lapierre H, Berthiaume R, Raggio G, Thivierge MC, Doepel L, Pacheco D, Dubreuil P and Lobley GE (2005). The rout of absorbed nitrogen into milk protein. Journal of Animal Science 80: 11-22.

Leng RA and Nolan JV (1984). Symposium: protein nutrition of the lactating dairy cows. Journal of Dairy Science 67: 10721089.

Leonhard-Marek S and Martens H (1996). Effects of potassium on magnesium transport across rumen epithelium. American Journal of Physiology 271: G1034-G1038.

Leonhard-Marek S, Stumpff F, Brinkmann I, Breves G and Martens H (2005). Basolateral $\mathrm{Mg}^{2+} / \mathrm{Na}^{+}$exchange regulates apical nonselective cation channel in sheep rumen epithelium via cytosolic $\mathrm{Mg}^{2+}$. American Journal of Physiology: Gastrointestinal Liver Physiology 288: G630G645.

Linzell JL, Setchell BP and Lindsay DB (1971). The isolated perfused liver of sheep: assessment of its metabolic, synthetic and secretory functions. Quarterly Journal of Experimental Physiology 56: 53-71.

MacKie RI and White BA (1990). Recent advances in rumen microbial ecology and metabolism: Potential impact on nutrient impact. Journal of Dairy Science 73: 29712995.

Mak DO, Dang B, Weiner ID, Foskett JK and Westhoff CM (2006). Characterization of ammonia transport by the kidney Rh glycoproteins RhBG and RhCG. American Journal of Physiology: Renal Physiology 290: F297-F305.

Maltby SA, Lomax MA, Beever DE and Pippard CJ (1991). The effect of increased ammonia and amino acid supply on post-prandial portal-drained viscera and hepatic metabolism in growing steers fed maize silage. In: Wenk $\mathrm{C}$ and Boessinger M (eds) Energy Metabolism of Farm Animals. European Association of Animal Production Publication no. 58, Zurich, Switzerland: ETH-Zentrum, pp. 20-23.

Maltby SA, Beever DE, Lomax MA, Crompton LA and Pippard CJ (1993a). The influence of diet and increased ammonia supply on energy and nitrogen metabolism across splanchnic tissues in growing cattle. Animal Production 56: 431 (Abstract).

Maltby SA, Crompton LA, Lomax MA, Beever DE and Pippard CJ (1993b). The effect of increased ammonia supply on postprandial hepatic metabolism in growing steers fed either forage or cereal-based diets. Proceedings of the Nutrition Society 52: 295A.

Marini AM, Matassi G, Raynal V, Andre B, Cartron JP and CherifZahar B (2000). The human Rhesus-associated RhAG protein and a kidney homologue promote ammonium transport in yeast. Nature Genetics 26: 341-344.

Marini JC and Van Amburgh ME (2003). Nitrogen metabolism and recycling in Holstein heifers. Journal of Animal Science 81: $545-552$.

Marini JC, Klien JD, Sands JM and Van Amburg ME (2004). Effect of nitrogen intake on nitrogen recycling and urea transporter abundance in lambs. Journal of Animal Science 82: $1157-1164$.

Marini JC, Sands JM and Van Amburgh ME (2006). Urea transporters and urea recycling in ruminants. In: Sejrsen $\mathrm{K}$, Hvelplund $\mathrm{T}$ and Nielsen $\mathrm{MO}$ (eds) Ruminant
Physiology. The Netherlands: Wageningen Academic Publishers, pp. 155-171.

Marsh MJ and Knepper MA (1992). Renal handling of urea. In: Windhager EE (ed.). Hand Book of Physiology, Renal Physiology. Oxford, UK: Oxford University Press, pp. $1317-1347$.

Martens $\mathrm{H}$ and Blume I (1986). Effect of intraruminal sodium and potassium concentrations and of the transmural potential difference on magnesium absorption from the temporarily isolated rumen of sheep. Quarterly Journal of Experimental Physiology 71: 409-415.

Martens H and Hammer U (1981). Magnesium and sodium absorption from the isolated sheep rumen during intravenous aldosterone infusion (author's transl.). Deutsche tierärztliche Wochenschrift 88: 404-407.

Martens H and Rayssiguier Y (1980). Magnesium metabolism and hypomagnesaemia. In: Ruckebusch Y and Thivend P (eds) Digestive Physiology and Metabolism in Ruminants. Clermont-Ferrand, France: MTP Press, pp. 447-466.

Martens H and Schweigel M (2000). Pathophysiology of grass tetany and other hypomagnesemias. Implications for clinical management, review. Veterinary Clinics of North America: Food Animal Practice 16: 339-368.

Martens H, Heggemann G and Regier K (1988). Studies on the effect of $\mathrm{K}, \mathrm{Na}, \mathrm{NH}_{4}{ }^{+}$, VFA and $\mathrm{CO}_{2}$ on the net absorption of magnesium from the temporarily isolated rumen of heifers. Zentralblatt für Veterinärmedizin. Reibe A 35: 73-80.

Martens H, Gäbel G and Strozyk B (1991). Mechanism of electrically silent $\mathrm{Na}$ and $\mathrm{Cl}$ transport across the rumen epithelium of sheep. Experimental Physiology $\mathbf{7 6}$ : 113-114.

Mathison GW and Milligan LP (1971). Nitrogen metabolism in sheep. British Journal of Nutrition 25: 351-366.

Mayer M, Schaaf G, Mouro I, Lopez C, Colin Y, Neumann P, Cartron JP and Ludewig U (2006). Different transport mechanisms in plant and human AMT/Rh-type ammonium transporters. Journal of General Physiology 127: 133-144.

McDonald IW (1948). The absorption of ammonia from the rumen of the sheep. Biochemical Journal 42: 584-587.

McLaren GA, Anderson GC, Martin WG and Cooper WK (1961). Fixation of ammonia nitrogen by rumen mucosa. Journal of Animal Science 20: 942-943.

Metges CC, Petzke KJ, El-Khoury AE, Henneman L, Grant I, Bedri S, Regan MM, Fuller MF and Young VR (1999). Incorporation of urea and ammonia nitrogen into ileal and fecal microbial proteins and plasma free amino acids in normal men and ileostomates. American Journal of Clinical Nutrition 70: 1046-1058.

Milano GD, Hotston-Moore A and Lobley GE (2000). Influence of hepatic ammonia removal on ureagenesis, amino acid utilization and energy metabolism in the ovine liver. British Journal of Nutrition 83: 307-315.

Nagami GT (1988). Luminal secretion of ammonia in the mouse proximal tubule perfused in vitro. Journal of Clinical Investigation 81: 159-164.

Nocek JE, Herbein J and Polan CE (1980). Influence of ration physical form, ruminal degradable nitrogen and age on rumen epithelial propionate and acetate transport and some enzyme activities. Journal of Nutrition 110: 23552364.

Nolan JV (1975). Quantitative models of nitrogen metabolism in sheep. In: McDonald IW and Warner ACI (eds) Digestion and Metabolism in the Ruminants. Armidale: University of New England, Australia, pp. 416-431.

Nolan JV and Strachin S (1979). Fermentation and nitrogen dynamics in Merino sheep given a low-quality-roughage diet. British Journal of Nutrition 42: 63-80. 
Nolan JV, Norton BW and Leng RA (1976). Further studies on the dynamics of nitrogen metabolism in sheep. British Journal of Nutrition 35: 127-147.

Norton BW, Mackintosh JB and Armstrong DG (1982). Urea synthesis and degradation in sheep given pelleted-grass diets containing flaked barley. British Journal of Nutrition 48: 249-264.

Obara Y, Dellow DW and Nolan JV (1991). Effects of energy-rich supplements on nitrogen kinetics in ruminants. In: Tsuda T, Sasaki Y and Kawashima R (eds) Physiological Aspects of Digestion and Metabolism in Ruminants. San Diego, CA: Academic Press, pp. 515-539.

Ortolani EL, Moris CS and Rodrigues Filho JA (2000). Ammonia toxicity from urea in a Brazilian dairy goat flock. Veterinary and Human Toxicology 42: 87-89.

Orzechowski A, Motyl T, Pierzynowski G and Barej W (1987). Hepatic capacity for ammonia removal in sheep. Journal of Veterinary Medicine 34: 108-112.

Parker DS, Lomax MA, Seal CJ and Wilton JC (1995). Metabolic implications of ammonia production in the ruminant, review. Proceedings of the Nutritional Society 54: 549563.

Paula S, Volkov AG, Van Hoek AN, Heines TH and Deamer DW (1996). Permeation of protons, potassium ions, and small polar molecules through phospholipid bilayers as a function of membrane thickness. Biophysical Journal $\mathbf{7 0}$ : 339-348.

Potter EA, Stewart G and Smith CP (2006). Urea flux across MDCK-mUT-A2 monolayers is acutely sensitive to AVP, CAMP, and $\left[\mathrm{Ca}^{2+}\right]$ i. American Journal of Physiology 291: R122-R128.

Remond D, Chaise JP, Delval E and Poncet C (1993a). Net transfer of urea and ammonia across the ruminal wall of sheep. Journal of Animal Science 71: 2785-2792.

Remond D, Poncet C and Lefaivre J (1993b). Technical note: ruminal vein catheterization and continuous blood flow measurement in ruminal arteries of sheep. Journal of Animal Science 71: 1276-1280.

Reynolds CK (1992). Metabolism of nitrogenous compounds by ruminant liver, review. Journal of Nutrition 122 (suppl. 3) 850-854.

Reynolds CK (1995). Quantitative aspects of liver metabolism in ruminants. In: Engelhardt Wv, Leonhard-Marek S, Breves G and Giesecke D (eds) Ruminant Physiology: Digestion, Metabolism, Growth and Reproduction. Stuttgart, Germany: Ferdinand Enke Verlag, pp. 351-372.

Reynolds CK (2006). Splanchnic amino acid metabolism in ruminants. In: Sejrsen K, Hvelplund T and Nielsen MO (eds) Ruminant Physiology. Wageningen, The Netherlands Wageningen Academic Publisher, pp. 225-248.

Reynolds CK and Huntington GB (1988). Partition of portaldrained visceral net flux in beef steer. 1 . Blood flow and net flux of oxygen, glucose and nitrogenous compounds across stomach and post-stomach tissues. British Journal of Nutrition 60: 539-551.

Reynolds CK and Tyrrell HF (1991). Effects of mesenteric vein L-alanine infusion on liver metabolism in beef heifers fed on diets differing in forage: concentrate ratio. British Journal of Nutrition 66: 437-450.

Reynolds CK, Tyrrell HF and Reynolds PJ (1991). Effect of diet forage -to- concentrate ratio and intake on energy metabolism in growing beef heifers: net nutrient metabolism by visceral tissues. Journal of Nutrition 121: 10041015.

Reynolds CK, Casper DP, Harmon DL and Milton CT (1992a). Effect of $\mathrm{CP}$ and ME intake on visceral nutrient metabolism in beef steers. Journal of Animal Science 70 (suppl. 1): 315 (Abstract).
Reynolds CK, Lapierre H, Tyrrell HF, Elsasser TH, Staples RC, Gaudreau P and Brazeau P (1992b). Effect of growthhormone releasing factor and feed intake on energy metabolism in growing beef steers: net nutrient metabolism by the portal-drained viscera and liver. Journal of Animal Science 70: 752-763.

Ritzhaupt A, Breves G, Schroder B, Winckler CG and ShiraziBeechey SP (1997). Urea transport in gastrointestinal tract of ruminants: effect of dietary nitrogen. Biochemical Society Transaction 25: S490 (Abstract).

Ritzhaupt A, Wood IS, Jackson AA, Moran BJ and ShiraziBeechey SP (1998). Isolation of a RT-PCR fragment from human colon and sheep rumen RNA with nucleotide sequence similarity to human and rat urea transporter isoforms. Biochemical Society Transaction 26: S122 (Abstract).

Rooke JA, Lee NH and Armstrong DG (1987). The effects of intraruminal infusions of urea, casein, glucose syrup and a mixure of casein and glucose syrup on nitrogen digestion in the rumen of cattle receiving grass-silage diets. British Journal of Nutrition 57: 89-98.

Satter LD and Slyter LL (1974). Effect of ammonia concentration on rumen microbial protein production in vitro. British Journal of Nutrition 32: 199-208.

Schwartz JH and Tripolone M (1983). Characteristics of $\mathrm{NH}_{4}{ }^{+}$ and $\mathrm{NH}_{3}$ transport across the isolated turtle urinary bladder. American Journal of Physiology 245: F210-F216.

Schweigel $\mathrm{M}$ and Martens $\mathrm{H}$ (2003). Anion-dependent $\mathrm{Mg}^{2+}$ influx and a role for a vacuolar $\mathrm{H}^{+}$-ATPase in sheep ruminal epithelial cells. American Journal of Physiology 285: G45-G53.

Schweigel M, Freyer M, Leclercq S, Etschmann B, Lodemann U, Bottcher A and Martens H (2005). Luminal hyperosmolarity decreases $\mathrm{Na}$ transport and impairs barrier function of sheep rumen epithelium. Journal of Comparative Physiology B 175: 575-591.

Scott D (1966). The effects of sodium depletion and potassium supplements upon electrical potentials in the rumen of the sheep. Quarterly Journal of Experimental Physiology and Cognate Medical Sciences 51: 60-69.

Scott D (1967). The effects of potassium supplements upon the absorption of potassium and sodium from the sheep rumen. Quarterly Journal of Experimental Physiology and Cognate Medical Sciences 52: 382-391.

Sehested J, Diernaes L, Moller PD and Skadhauge E (1999). Transport of butyrate across the isolated bovine rumen epithelium. Interaction with sodium, chloride and bicarbonate. Comparative Biochemistry and Physiology A $\mathbf{1 2 3}$ 399-408.

Sellers AF and Dobson A (1960). Studies on reticulorumen sodium and potassium concentration and electrical potentials in sheep. Research in Veterinary Science 1: 95 .

Siddons RC, Nolan JV, Beever DE and McRae JC (1985). Nitrogen digestion and metabolism in sheep consuming diets containing contrasting forms and levels of N. British Journal of Nutrition 54: 545-561.

Simmonet H, Le Bars H and Molle J (1957). Le cycle de l'urée administrée par voie buccale chez les ruminants (Urea cycle after oral administration to ruminants). Séance Académique Science 244: 943-945.

Sinclair LA, Garnsworthy PC, Newbold JR and Buttery PJ (1993). Effect of synchronising the rate of dietary energy and nitrogen release on rumen fermentation and microbial protein synthesis in sheep. Journal of Agricultural Science 120: 251-263.

Singh SK, Binder HJ, Geibel JP and Boron WF (1995). An apical permeability barrier to $\mathrm{NH}_{3} / \mathrm{NH}_{4}{ }^{+}$in isolated, perfused 
colonic crypts. Proceedings of the National Academy of Sciences, USA 92: 11573-11577.

Sniffen CJ and Jacobson DR (1975). Net amino acid absorption in steers fed alfalfa hay cut at two stages of maturity. Journal of Dairy Science 58: 371-385.

Sperber I and Hyden S (1952). Transport of chloride through the ruminal mucosa. Nature 169: 587.

Stacy BD and Warner AC (1966). Balances of water and sodium in the rumen during feeding: osmotic stimulation of sodium absorption in the sheep. Quarterly Journal of Experimental Physiology and Cognate Medical Sciences 51: 79-93.

Stewart GS, Graham C, Cattell S, Smith TPL, Simmons NL, Smith CP (2005). UT-B is expressed in bovine rumen: potential role in ruminal urea transport. American Journal of Physiology 289: R605-R612.

Stumpff F and Martens H (2006). A role for magnesium in the regulation of ruminal sodium transport. In: McAlpine G (ed.) Focus on Signal Transduction Research. Hauppauge, NY: Nova Science Publishers, Inc., Chapter 2, pp. 36-66.

Symonds HW, Mather DL and Collis KA (1981). The maximum capacity of the liver of the adult dairy cow to metabolize ammonia. British Journal of Nutrition 46: 481-486.

Taminga S (1983). Recent advances in our knowledge on protein digestion and absorption in ruminants. In: Arnal M, Pion R and Bonin D (eds) Proceedings of the 4th International Symposium of European Association of Animal Production (EAAP), Protein Metabolism and Nutrition. Paris: INRA, pp. 263-287.

Theurer CB, Huntington GB, Huber JT, Swingle RS and Moore JA (2002). Net absorption and utilization of nitrogenous compounds across ruminal, intestinal, and hepatic tissues of growing beef steers fed dry-rolled or steam-flaked sorghum grain. Journal of Animal Science 80: 525-532.

Thompson DJ, Beever DE, Lonsdale CR, Haines MJ, Cammell SB and Austin RA (1981). The digestion by cattle of grass silage made with formic acid and formic acid-formaldehyde. British Journal of Nutrition 46: 193-207.

Thorlacius SO (1972). Effect of stream-volatile fatty acids and carbon dioxide on blood content of rumen papillae of the cow. American Journal of Veterinary Research 33: $427-430$.

Thorlacius SO, Dobson A, Sellers AF (1971). Effect of carbon dioxide on urea diffusion through bovine ruminal epithelium. American Journal of Physiology 220: $162-170$
Torrallardona D, Harris CI and Fuller MF (2003). Pigs' gastrointestinal microflora provide them with essential amino acids. Journal of Nutrition 133: 1127-1131.

Warner AC and Stacy BD (1972a). Water, sodium and potassium movements across the rumen wall of sheep. Quarterly Journal of Experimental Physiology and Cognate Medical Sciences 57: 103-119.

Warner AC and Stacy BD (1972b). Intraruminal and systemic responses to variations in intake of sodium and potassium by sheep. Quarterly Journal of Experimental Physiology and Cognate Medical Sciences 57: 89-102.

Warner AC and Stacy BD (1977). Influence of ruminal and plasma osmotic pressure on salivary secretion in sheep. Quarterly Journal of Experimental Physiology 62: 133-142.

Webb DW, Bartley EE and Meyer MR (1972). A comparison of nitrogen metabolism and ammonia toxicity from ammonium acetate and urea in cattle. Journal of Animal Science 35: $1263-1270$.

Weiner ID (2004). The Rh gene family and renal ammonium transport. Current Opinion in Nephroogyland Hypertension 13: $533-540$.

Wernli CG and Wilkins RJ (1980). Nutritional studies with sheep fed conserved grass. 1. Silage and dried grass offered ad libitum without supplements. Quarterly Journal of Experimental Physiology 60: 89-94.

Westhoff CM, Ferreri-Jacobia M, Mak DO and Foskett JK (2002). Identification of the erythrocyte Rh blood group glycoprotein as a mammalian ammonium transporter. Journal of Biological Chemistry 277: 12499-12502.

Wilton JC, Gill M and Lomax MA (1988). Uptake of ammonia across the liver of forage-fed cattle. Proceedings of the Nutrition Society 47: 153A.

Winkler FK (2006). Amt/MEP/Rh proteins conduct ammonia. European Journal of Physiology 451: 701-707.

Wolf JE, Bergman EN and Williams HH (1972). Net metabolism of plasma amino acids by liver and portal drained viscera of fed sheep. American Journal of Physiology 223: 438-446.

Wolffram S, Frischknecht R and Scharrer E (1989). Influence of theophylline on the electrical potential difference and ion fluxes $(\mathrm{Na}, \mathrm{Cl}, \mathrm{K})$ across the isolated rumen epithelium of sheep. Zentralbl Veterinarmed A 36: 755-762.

Wrong OM (1978). Nitrogen metabolism in the gut. American Journal of Clinical Nutrition 31: 1587-1593.

Yellen G (1987). Permeation in potassium channels: implications for channel structure. Annual Review of Biophysics and Biophysical Chemistry 16: 227-246. 